\title{
Çalışanların Sosyal Medya Kullanımının Yenilikçi Performans Üzerindeki Etkisinin Araştırılması1 ${ }^{1}$
}

\author{
DOI: 10.26466/opus.635371 \\ $*$

\begin{abstract}
Yunus Bahadır Güler*- Nurgül Göksal**
* Doç.Dr, Kırıkkale Üniversitesi, Keskin Meslek Yüksek Okulu, Keskin/ Kırıkkale/ Türkiye E-Posta: ybguler@hotmail.com

ORCID: 0000-0002-8350-2721

** Doktora Öğr., Kırıkkale Üniversitesi, Sosyal Bilimler Enstitüsü, Yahşihan/ Kırıkkale/ Türkiye

E-Posta: nurgul.ornek@hotmail.com

ORCID: 0000-0003-2006-6675
\end{abstract}

\section{Öz}

İşletmelerde sosyal medya kullanımı son yıllarda hızlı bir artış göstermektedir. İşletmelerde çalışanlar tarafindan kullanılan sosyal medya iş amaçlı ve sosyal amaçlı olmak üzere iki şekilde ele alınmaktadır. İş amaçlı sosyal medya kullanımında, çalışanlar iş arkadaşlarıyla ve işletme paydaşlarıyla temel işle ilgili bilgi ve içerik alışverişini sağlamalarının yanında örgütsel elçiler olarak kurumsal itibara da katkı sağlamaktadırlar. Sosyal amaçlı sosyal medyada ise çalışanların gayri resmi, kişisel, sosyal ve duygusal etkileşimleri esas olmaktadır. İşletmelerde çalışanlar tarafindan kullanılan sosyal medyanın ilişkili olabileceği hususlardan biri de çalışanların iş tanımlarının ötesinde yenilikçi davranışlarda bulunmasın ifade eden yenilikçi performanstır. Bu araştırma işletmelerde iş amaçlı ve sosyal amaçlı sosyal medya kullanımı ile yenilikçi performans arasındaki ilişkinin varlı̆̆ını sorgulamak amacı ile yapılmıştır. Bu amaçla Ankara ilinde Bankacılık sektöründe 127 çalışanı kapsayan bir araştırma yürütülmüştür. Araştırmada anket yöntemi kullanılmıştır. Araştırma sonucu, sosyal amaçl sosyal medya kullanımı ile yenilikçi performans arasında anlamlı bir iliş̧ki olmadı̆̆ $\imath$; iş amaçl sosyal medya kullanımı ile yenilikçi performans arasında ise anlamlı bir ilişsinin olduğu tespit edilmiştir.

Anahtar Kelimeler: Sosyal Medya, İş Amaçlı Sosyal Medya, Sosyal Amaçlı Sosyal Medya, Yenilikçi Performans.

\footnotetext{
${ }^{1}$ Bu çalışma "işletmelerde Sosyal Medya Kullanımının Işse Adanmışık, Çalışan Sadakati ve Bireysel Performansa Etkisi" adlı doktora tezinden türetilmiştir
} 


\title{
Investigation of Employees' Effect of Social Media on Innovative Performance
}

\begin{abstract}
The use of social media in enterprises has increased rapidly in recent years. The social media used by the employees in the enterprises are handled in two ways as business and social purposes. In the use of social media for business purposes, employees contribute to the corporate reputation as organizational ambassadors as well as providing basic business-related information and content exchange with colleagues and business stakeholders. In social media for social purposes, informal, personal, social and emotional interactions of employees are essential. One of the issues that the social media used by the employees in the enterprises may be related to is the innovative performance that expresses the employee's innovative behaviors beyond the job descriptions. This research was conducted to investigate the existence of the relationship between the use of social media for business and social purposes and innovative performance. Fort this purpose, a research was conducted on 127 employees working in the banking sector in Ankara. Survey method was used in the research. The results of the study indicated that there was no significant relationship between social use and innovative performance; The relationship between business social media use and innovative performance was found to be significant.
\end{abstract}

Keywords: Social Media, Social Media for Business Purposes, Social Media for Social Purposes, Innovative Performance 


\section{Giriş}

Sosyal medyanın işletmelerde iş amaçlı ve sosyal amaçlı kullanımı, literatürde az sayıda incelenen ve örgütsel etkisi araştırılan bir konu olmaktadır. Konu ile ilgili literatür araştırması yapıldığında işletmedeki çoklu sosyal medya kullanımının (iş amaçlı ve sosyal amaçlı) çalışanların yenilikçi performanslarını nasıl etkilediğine dair bir çalışmaya rastlanmamaktadır. Ancak sosyal medyanın popülerliği göz önünde bulundurulduğunda bu konu ile ilgili önümüzdeki yıllarda geniş bir literatür oluşacağ tahmin edilebilmektedir.

Sosyal medya kavramı için evrensel olarak kabul edilen bir tanımlama yapılmamakla birlikte genel olarak bazı araştırmacılar tarafından sosyal etkileşim, topluluk oluşumu ve işbirlikçi projelerin ele alınması için bir alan sağlayan Web 2.0 teknolojileri üzerine inşa edilen web siteleri olarak tanımlanmaktadır (Bruns, 2009, s.7). İşletmelerde sosyal medya kullanım amaçları işle ilgili ve sosyal amaçla ilgili olmaktadır. İş amaçlı sosyal medya, işyerinde kaynak yaratma, işbirliği ve görev yönetimi, iş ve olayların izlenmesi, resmi iç kurumsal iletişim gibi temel işle ilgili bilgi ve içerik alışverişini kolaylaştırmak için kullanılabilecek web tabanlı platformlara atıfta bulunmaktadır. Sosyal amaçlı sosyal medya ise sosyal ve kişisel bilgilerin değişimini sağlayan web tabanlı platformlara atıfta bulunmakta ve gayri resmi, kişisel, sosyal, duygusal etkileşimler içindir (Song, vd., 2019, s.15).

Sosyal medya, işletmelerin ve çalışanlarının, işletme içinde ve dışında iletişim kurma, işbirliği yapma, tüketme ve yaratma biçimlerini kökten değiştirmiştir (Aral vd., 2013, s.3). Facebook, Twitter,

YouTube gibi sosyal ağ uygulamaları işletmeler tarafından giderek değişik şekillerde kullanılmaktadır. İşletmeler müşterileri ile ilişki kurmak ve çalışanlar arasındaki iletişimi desteklemek de dâhil olmak üzere çeşitli nedenlerle sosyal medya kullanımını benimsemektedir. Sosyal medya çalışanlar arasındaki iletişimi potansiyel olarak destekleyebilmesine rağmen her zaman ilgili iş amaçlarına uygun bir şekilde kullanılmalarına da dikkat edilmesi gerekmektedir (Taylor, vd.,2016, s.8).

Çalışanların performansı işletmelerin etkinliğini ve başarısını geliştirmede temel rol oynamaktadır. Bu nedenle sürekli eğitim ve gelişim programları ile çalışanların performansının geliştirilmesine artan bir ilgi bu- 
lunmaktadır. Son yıllarda işletmeler artan rekabet baskıları karşısında insan kaynaklarını optimize etmek için çaba harcadıkça performans yönetimi ön plana çıkmıştır. Diğer bazı örgütsel kavramların aksine araştırmacılar arasında performansın işletmelerde önemli bir değişken olduğu konusunda genel bir anlayış bulunmaktadır (Suliman, 2001, s.1049). Örgütsel performans ve rekabet gücü çalışanların performansına göre belirlenmektedir. İnsan kaynakları yönetimindeki uygulamalar ile örgütsel performans ile rekabetçilik arasındaki pozitif ilişkiyi sağlamak mümkün olmaktadır. Şöyle ki, işletmeler yetenekli çalışanları istihdam edip, onların motive olmalarını sağlayarak, çalışanlarını geliştirerek ve istenen çalışan performansını elde ederek yüksek örgütsel performans ve rekabetçilik sağlanmış olmaktadır (Sikyr, 2013, s.48).

Bazı araştırmacılar çalışan performansına tek boyutlu bir kavram olarak baksa da, çoğu araştırmacı çalışan performansının çok boyutlu bir yapıya sahip olduğunu ileri sürmektedir (MdSidin,vd., 2009, s.53). Bu çalışmada Katz (1964)'ın çalışmasına dayanarak Jassen (2004) tarafından geliştirilen çalışan performansının iki boyutu olan rutin performans ve yenilikçi performans boyutlarından sadece yenilikçi performans boyutu ele alınmaktadır. Rutin performans, bireyin iş tanımında belirtilen görev ve sorumlulukların yerine getirilmesi iken yenilikçi performans bireyin iş tanımının ötesine geçen işletmenin yararına olan isteğe bağlı davranışlarda bulunması, işletmede yeni fikirlerin üretilmesi, benimsenmesi ve uygulanması için gerekli gücün kazanılmasını ifade etmektedir.

Bu çalışma ile işletmedeki iş amaçlı ve sosyal amaçlı sosyal medya kullanımının çalışanların yenilikçi performansını ne yönde etkilediği araştırılmaktadır. Bu kapsamda öncelikli olarak konu ile ilgili kavramsal çerçeve oluşturulacak, sonrasında yapılan araştırma ile ilgili bilgi ve bulgular yer alacaktır.

\section{Kavramsal Çerçeve}

Günümüzde sosyal medya örgütsel amaçların gerçekleştirilmesinde giderek daha fazla kabul görmüştür. İşletmelerin sosyal medya girişimleri işletme içinde ve dışında iş akışının yürütülmesinde kolaylıklar sağlamakta ve bu durumun çalışan performansını etkilediği düşünülmektedir. İşletmelerde sosyal medya kullanımı kavramının literatürde araştırılmasıyla 
birlikte bu kavramın çeşitli bireysel ve örgütsel düzeyde çıtıları da araştırılmaya konu olmuştur. Bu açıdan sosyal medyanın yenilikçi performans ile ilişkisi incelemeye değer görülmüştür.

\section{Sosyal Medyanın İşletmelerde Kullanımı}

İşletmelerde sosyal medya kullanımı daha önce görülmemiş bir hızla gelişme göstermektedir. İşletmeler için önemli olan husus, işletmelerin sosyal medya platformlarından hangisini kullanacak olması değil, belirli bir platformun nasıl kullanıldığı ve bu platformlarda yaratılan ve paylaşılan bilgilerdir (Culnan vd. 2010'dan akt. Piller, vd.,2011, s.2).

İşletmelerde sosyal medya kullanım amaçları; iş amaçlı ve sosyal amaç11 olmaktadır. Song ve arkadaşlarına (2019) göre iş amaçlı sosyal medya, işyerinde kaynak yaratma, işbirliği ve görev yönetimi, iş ve olayların izlenmesi, resmi iç kurumsal iletişim gibi temel işle ilgili bilgi ve içerik alışverişini kolaylaştırmak için kullanılabilecek web tabanlı platformlara atıfta bulunmaktadır. Sosyal amaçlı sosyal medya ise sosyal ve kişisel bilgilerin değişimini sağlayan web tabanlı platformlara atıfta bulunmakta ve gayri resmi, kişisel, sosyal, duygusal etkileşimler için kullanılmaktadır (Song, vd., 2019, s.15). Gonzales ve arkadaşlarına (2013) göre iş amaçlı sosyal medya kullanımı; çalışanların iş projeleriyle ilgili güncellemeler paylaşma$\mathrm{s} 1$, iş arkadaşları ile iş projeleri hakkında toplantılar düzenlemesi, iş arkadaşları ile örgütsel amaçlar hakkında bilgi paylaşması, işletme politikaları ve prosedürleri hakkında bilgi paylaşması, çalışma dosyalarını düzenlemesi, ileride kullanmaları için güvenilir bilgiler yüklemesi, belirli alandaki uzmanlıklarını paylaşmak ve belirli bir alandaki uzmanlığı olan başka çalışanlara erişim sağlamaktadır. Sosyal amaçlı sosyal medya kullanımı ise; çalışanların çalışma saatlerinden sonra iş arkadaşlarıyla sosyal etkinlikler düzenlemesi, işletme içinde arkadaş edinmesi, işe ara vermesi, işteyken başkalarıyla sohbet etmesi ve benzer ilgi alanlarına sahip kişileri bulmasıdır (Gonzales vd., 2013, s.8).

Zoonen ve arkadaşlarına (2014) göre, sosyal medyanın işle ilgili bir bağlamda kullanılması birden fazla işleve hizmet etmektedir. Bu işlevler, bilgi yayma, ilişki yönetimi ve örgütsel elçilik için bir araç olarak kullanılmasıdır. İlk olarak, işle ilgili sosyal medya kullanımı, çalışanlara ve işletmelerine iş arkadaşlarıyla ve diğer paydaşlarla iletişim kurma ve ilişkiler 
kurma konusunda yeni yollar sunmaktadır. Sosyal medya çalışanlar arasındaki farkındalığı ve iletişimi artırabilir (Mukherjee vd. 2012'den aktaran Zoonen vd., 2014, s.851). İkinci fayda, sosyal medya işletmelerde bilgiyi yayma aracı olarak kullanılmakta ve böylece çalışanların işle ilgili konular hakkında fikir edinmeleri kolaylaşmaktadır. Üçüncü fayda ise işle ilgili sosyal medya kullanımı çalışanların örgütsel elçilikle meşgul olmaları için bir platform sağlamaktadır. Çalışanlar kişisel sosyal medya ağları aracılığıyla örgütsel itibara çevrimiçi elçiler olarak katkıda bulunmaktadır. Bu açıdan çalışanların çevrimiçi faaliyetleri kurumsal iletişim ve itibar için ek bir değer olduğu düşünülmektedir. Bu nedenle işletmelerin sosyal medyaya erişimi sınırlandırıcı ve kısıtlayıcı çabaları yanlış yönlendirilmiş bulunmaktadır (Zoonen vd., 2014, s.851).

Zoonen ve arkadaşlarına (2017) göre iş için sosyal medya kullanımının olumlu ve olumsuz sonuçları bulunmaktadır. Spesifik olarak iş için sosyal medya kullanımı olumlu ve olumsuz olacak şekilde iki farklı psikolojik süreci (motivasyonel süreci ve sağlik bozukluğu süreci) tetikleyebilir. Olumlu sonuçlar motivasyonel bir süreci tetikler; etkili iletişim ve erişilebilirliği öne sürmek, iş hedeflerine ulaşmada ve temel psikolojik ihtiyaçların karşılanmasında işlevseldir ve böylece çalışanların katılım duygusuna katkıda bulunmaktadır. Bununla birlikte sosyal medya platformlarında artan bağlantı ve çeşitli sosyal gruplar günlük iş süreçlerinde kesintilere neden olmakta ve bu durum çalışanların iş- yaşam çatışmalarını artırmaktadır. Bu durum çalışanların psikolojisini etkileyebileceğinden çalışanların sağlik bozukluğu sürecini tetiklemektedir (Zoonen vd., 2017, s.602).

Song ve arkadaşlarına (2019) göre iş amaçlı ve sosyal amaçlı sosyal medya birbirinin tamamlayıcıları olmakta, çünkü bu iki teknolojinin ortak kullanımı, çalışanların iş arkadaşlarıyla çok yönlü ilişki kurmasına yardımcı olmaktadır. Çalışmaya yönelik sosyal medyaya yerleştirilmiş olan kurumsal sicil yardımı ile çalışanlar daha az tanımış oldukları ya da şahsen tanışma fırsatı bulamadıkları iş arkadaşlarını (örneğin dağıtılmış bir ekipte çalışanlar) kolayca arayabilir ve onlarla iletişim kurabilir. Buna karşllık sosyalleşme amaçlı sosyal medya duygusal iletişim ve ilişki geliştirmeye odaklanarak iş amaçlı sosyal medyayı tamamlayabilmektedir. Örneğin çalışanlar sosyalleşme amaçlı sosyal medyayı kişisel ilgi alanlarını spor, müzik veya diğer konularda paylaşmak için kullanabilirler. Çalışanların benzer çıkarları olan iş arkadaşlarını bulması ve bu çıkarlara dayalı 
sosyal ilişkiler geliştirmesi yararlı olmakla birlikte, bu durum onların psikolojik veya duygusal mesafelerini kısaltabilmektedir (Song, vd., 2019, s.4).

Literatür sosyal medya bağlamında, sosyal medyanın dijital reklamcllık ve tanıtımda, müşteri hizmetleri konularını ele almada, yenilikçi fikirleri benimsemede ve müşteri ilişkileri kurmada önemli bir etkiye sahip olabileceğini iddia etmektedir (Solis 2010'dan akt. Tajuderen vd., 2018, s.310). Bu nedenle işletmeler pazarlama, müşteri ilişkileri ve bilgi arama gibi çeşitli görevler için sosyal medyayı etkin bir şekilde kullandıklarında özellikle maliyet düşürme, müşteri ilişkilerinde iyileştirmeler ve daha fazla erişilebilirlik açısından işletme üzerinde olumlu bir etki yaratması muhtemeldir (Tajudeen vd., 2018, s.310). İşletmeler bir süredir markalaşma, pazarlama ve işe alım gibi dış faaliyetler için sosyal medyayı etkili bir araç olarak kullanmakla birlikte son zamanlarda işletmelerin sosyal medyayı çalışanlar arasında kurum içi işbirliğini, iletişimi, bilgi paylaşımını ve yeniliği geliştirmek için bir araç olarak benimsemelerinde bir artış olmuştur (Rathore ve Panwar, 2016, s.3).

Kamu kurum ve kuruluşlarından küçük işletmelere kadar tüm işletmeler sosyal medya kullanımını giderek artan oranda stratejik yönetim, örgütsel iletişim ve halkla ilişkileri ile uyumlu hale getirmektedir. Bu durum çoğu kişi tarafından olumlu bir gelişme olarak değerlendirilmekte, Web 2.0 ortamının sağladığı açıklık; demokrasiyi, katılımcllı̆̆ı, iletişimi ve topluluk oluşturmayı mümkün kılmaktadır (Macnamara ve Zerfass, 2012, s.287).

Sosyal medyanın işletmelerde benimsenmesi ve kullanımının nasıl yönetileceği önemli bir husus olmaktadır. Doğru bir şekilde yönetildiğinde, sosyal medyanın işletmelere net faydalar sağladığı görülmüştür (Chung vd., 2018, s.33). Sosyal medyanın yanlış yönetilmesi ise, işletme ve paydaşları için önemli ve istenmeyen sonuçlar doğurabilir (Chung vd., 2017, s.1405). Bu nedenle işletmelerde çalışanlara sosyal medya eğitimi verilmesi gerekmektedir. Bu eğitim yalnızca belirli araçların nasıl kullanılacağına odaklanmayı değil, aynı zamanda hangi araçların kullanılacağını ve bunların etkin bir şekilde nasıl ölçüleceğini de belirlemeyi içermelidir. İşletmeler sürekli güncellenen sosyal medya platformlarında etkin bir şekilde gezinmek için hazırlıklı olmalıdır (DiStaso vd., 2011, s.327). 


\section{Yenilikçi Performans}

Performans kavramı günlük hayatta, iş hayatında ve eğitim hayatında olmak üzere birçok alanda sıklıkla kullanılan bir kavram olarak karşımıza çıkmaktadır. Literatürde performans kavramı ile ilgili çeşitli tanımlamalar yapılmaktadır. Bireysel performans, çalışanların yetenek ve motivasyonlarını kullanarak işletmelerin beklenen hedeflere ulaşmalarını sağlayan davranış ve sonuçlanı ifade etmekte iken örgütsel performans işletme sonuçları (verimlilik, kalite v.b), pazar sonuçları (satış, pazar payı, müşteri memnuniyeti v.b) ve finansal sonuçları (maliyetler, gelirler, kârlar v.b) ifade etmektedir. Örgütsel performans ve rekabet edilebilirliğin çalışan performansına göre belirlendiğine dair önemli kanıtlar bulunmaktadır (Sikyr, 2013, s.48). Diğer bir değişle çalışanların performansının ölçülmesi ve teşvik edilmesi, örgütsel başarının ve rekabet avantajının kilit bir belirleyicisi olmaktadır (Ployhart vd. 2006'dan akt. Jouda vd., 2016, s.1083).

Bir işletmede çalışanların yüksek performans göstermesi veya başarılı olması birçok faktörün katkısıyla oluşmaktadır. Bu karışımın oluşmasında çalışanların konuşma, anlama, fiziksel güç gibi kişisel yetenekleriyle çalışanların bu yetenekleri ortaya koyma isteğinin yoğunluğu, çalışanın içinde bulunduğu fiziksel ortam, işletmenin faaliyet sürdürdüğü çevresel koşullar, işletmenin çalışanlarına yönelik politika ve felsefelerini yansıtan örgütsel koşullar rol oynamaktadır (Bingöl, 2014, s. 368).

Çalışan performansının yüksek tutulmasında pek çok faktör etkili olmaktadır. Bunlar arasında çalışanların moralinin yüksek tutulması önemli bir husus olmaktadır. Bu da çalışanlara verilen ücretin istenilen düzeyde olması, terfi sisteminin düzgün bir şekilde işlemesi, çalışanlara verilen ödül ve prim sistemlerinin adil olması, çalışanların sosyal hak ve imkanlardan faydalanması, çalışanların fikirlerine saygı gösterilerek içtenlikle davranılması ile mümkün olmaktadır (İraz ve Akgün, 2011, s.228).

Birçok araştırmacı bireysel performansı tek boyutlu bir kavram olarak ele alsa da, çoğu araştırmacı performansın çok boyutlu bir yapıya sahip olduğunu ileri sürmektedir (Md-Sidin vd., 2009, s.53).

Katz (1964) bireysel performansı rutin faaliyetler ve yenilikçi faaliyetler gibi iki boyuttan oluşan bir kavram olarak tanımlamaktadır (Katz, 1964, s.132). Sparrowe ve arkadaşları (2001) ise bireysel performansı rol içi performans/rutin performans (gerekli görev ve sorumlulukların yerine geti- 
rilmesi) ve ekstra rol performansi/yenilikçi performans (resmi iş tanımının ötesine geçen isteğe bağlı davranışlarda bulunma) şeklinde iki yönlü ele almaktadır (Sparrowe vd., 2001, s.14). Rol içi performansta, bir çalışanın iş tanımında belirtilen ve istenen eylemler tanımlanmakta, böylece çalışan işletme tarafından değerlendirilip ödüllendirilmektedir. Bir işletme iş performansını öngörülebilir hale getirmek için kurallar ve prosedürleri kullanmak ile çalışanlara sorunlara, fırsatlara ve olağan dışı durumlara uyum sağlamak için kendiliğinden yenilik yapma özgürlüğünü vermek arasında doğru dengeyi bulmak zorundadır. Yenilikçi performans, bir gruba veya organizasyona fayda sağlamak için yeni fikirlerin kasıtlı olarak üretilmesi, tanıtılması ve gerçekleştirilmesi olarak tanımlanmaktadır (Jassen, 2004, s.370). Yenilikçi performans, sorunlarla, fırsatlarla ve olağan dışı durumlarla ilgilenir ve diğer şeylerin yanı sıra fikirlerin üretilmesi ve benimsenmesi, koalisyon kurma ve yenilikleri başarıyla uygulamak için gerekli gücün kazanılmasını içermektedir. Bu görevler aynı anda ve sırayla bireyler tarafından gerçekleştirilmekte ve örgütsel yeniliğin özünü temsil etmektedir (Hassam vd., 2015, s.71).

\section{Araştırma Metodolojisi}

\section{Araştırmanın Amacı ve Önemi}

İşletmelerde çalışanlar tarafından kullanılan sosyal medyanın biçimsel (iş amaçlı) ve biçimsel olmayan (sosyal amaçlı) boyutları bulunmaktadır. Araştırmada sosyal medyanın çalışanların iş ilişkilerinin rahatlıkla yürütülmesi adına işletmeler tarafından oluşturulan, kontrol altında tutulan biçimsel boyutunun; bununla birlikte sosyal medyanın kontrol altında tutulamayan biçimsel olmayan boyutunun çalışanların yenilikçi performansları üzerindeki etkisinin belirlenmesi amaçlanmaktadır.

Sosyal medyanın iş hayatında yaygınlaşmasıyla birlikte, işletmelerde çalışanların sosyal medya kullanımı, yönetim tarafından kontrol edilmesi mümkün olduğu kadar, kontrol edilemediği durumlar da söz konusu olmaktadır. Bu araştırma ile çalışanların sosyal medya kullanımlarının yenilikçi performans üzerindeki etkisi belirlenerek bu şekilde işletmelerde buna ilişkin önlemlerin alınması ve uygulamaların daha iyi yapılması sağlanacaktır. 


\section{Araştırmanın Sınırlılıkları}

Araştırma kapsamında belirtilen sınırlılıklar aşağıda yer almaktadır.

- Araştırma sonuçları sadece Ankara ili ile sınırlı kalmakta ve dolayısıyla diğer illerdeki işletme ve çalışanlara genellenememekte,

- Araştırmada incelenen değişkenler, sosyal medya ölçeği, yenilikçi performans ölçeği sonucu elde edilen verilerle sınırlı olmakta,

- Araştırma kapsamında elde edilen sonuçlar 01.07.2019-30.08.2019 tarihleri arası ile sinırlı olmaktadır.

- Araştırma sonucu bankacılık sektörü dışındaki işletmelerde bulgular geçerli olmayabilir.

\section{Araştırmanın Hipotezleri}

$\mathrm{Bu}$ araştırmanın dayandığı değişkenler; iş amaçlı sosyal medya, sosyal amaçlı sosyal medya ve yenilikçi performans olmaktadır. Literatür incelemesi yapıldığında kuramsal bağlamda sosyal medya ile yenilikçi performans arasındaki ilişkileri esas alan çalışmaların bulunmamasına rağmen dolaylı olarak sosyal medya ile bireysel performans arasındaki ilişkiye dair çeşitli çalışmaların bulunduğu görülmektedir.

Nduhura ve Prieler (2017)'in çalışmasında çalışanların işyerinde özel ve iş amaçlı sosyal medya kullanımını araştırmıştır. Araştırmaya katılanların bakış açısına göre sosyal medya kamu kurumlarının işleyişinde giderek daha önemli bir rol oynamaktadır. Genel olarak sosyal medyanın kurumları olumlu yönde etkilediği ifade edilmektedir. Çünkü sosyal medya aracılığıyla işyerinde faaliyetler hızlı bir şekilde organize edilir (örn; toplantı düzenleme, sipariş verme gibi), mesajlar aynı anda birçok çalışanla paylaşılmakta ve geri bildirimler hılı olmaktadır. Özellikle whatsapp grupları tüm kurumlarda popüler bir şekilde kullanılmaktadır. Bu değiş tokuşlar bireysel cep telefonları, dizüstü bilgisayarlar veya kurumun bilgisayarları aracılığıyla gerçekleşmektedir. Ancak cep telefonları daha çok saha çalışmasına katılan çalışanlar tarafından kullanılmaktadır (Nduhura ve Prieler, 2017, s.712-713).

Bununla birlikte Nduhura ve Prieler (2017) çalışmasında kamu kurumlarında raporlamanın önceki durumlardan çok daha pratik hale geldiği sonucunu elde etmiştir. Şöyle ki bazı çalışanlar sosyal medyada kısa me- 
sajlar kullanarak günlük olarak ne yaptıklarını rapor ettiklerini açklamıştır. Bu mesajlar hem çalışanlar hem işverenleri bir araya getiren gruplar aracılığıyla paylaşılmaktadır. Ayrıca sosyal medya taranacak ve farklı ulaşım araçlarıyla gönderilecek resmi belgelerin sayısını azaltarak kurum yönetiminde önemli ölçüde fayda sağlamıştır. Sosyal medya aynı zamanda çalışanlara ve işletmelere aynı faaliyetleri veya çıkarları paylaşan ve böylece ortaklıklar sağlayan daha geniş bir insan ve kurum ağına sahip olmalarında yardımc olmaktadır. Sosyal medyanın bir diğer faydası ise çalışanların farklı paydaşlarla iletişimi söz konusu olduğunda diğer medya türlerine göre çok daha pratik olduğudur. Araştırmaya katılan bazı katılımıcılar sosyal medyanın iş stresini azaltma konusunda önemli bir katkısının bulunduğu ve daha fazla başarma isteklerini artırdıkları belirtilmektedir (Nduhura ve Prieler, 2017, s.712-713).

Nduhura ve Prieler (2017) çalışmasında sosyal medyanın özel kullanımının kamu kurumlarında verimliliği artırdığına dair somut bir kanıt bulamamakla birlikte çalışanların refahı için önemli olduğu sonucuna ulaşmıştır. Çalışanların yakınlarıyla iletişim kurması, günlük problemlerini çözmesi ve toplumun faaliyetlerine katılması enerji verici olmaktadır. Sonuç olarak sosyal medya kullanımının çalışanların verimliliğine değer kattığı görülmektedir. Araştırmada edindiği bulgular sosyal medyanın yararları hakkında mevcut literatür ile hemfikirdir. Örneğin araştırma Facebook'un işte kullanılmasının çalışanların ruh halini olumlu yönde etkilediğini ve çalışmalarında kendilerini daha iyi hissetmelerini sağladığını göstermiştir. Bu açılardan sonuç olarak işletmelerde sosyal medyanın özel kullanımına tolerans gösterilmesi uygun görülmüştür (Nduhura ve Prieler, 2017, s.714-715).

Zoonen ve arkadaşları (2014) çalışmasında çalışanların iş amaçlı sosyal medya kullanımını incelemiş ve çalışanların örgütsel amaçlara katkıda bulunmak için kişisel sosyal medya hesaplarını isteyerek kullandıklarını ifade etmektedir. Bu çalışma, çalışanların sosyal medya kullanımına yönelik motivasyonlarını incelemekte ve çevrimiçi örgütsel duyum sağlamaya katkılarının araştırılması için bir araştırma başlangıç noktası sunmaktadır. Zoonen ve arkadaşları (2014) çalışmasında iş amaçlı sosyal medya kullanımının iç tutarlılığı artırdığı ve iletişim süreçlerini yumuşattığı sonucuna ulaşmıştır. Bununla birlikte çalışanlar sosyal medya ağları aracılığıyla çevrim içi elçiler olarak kurumsal itibara katkıda bulunmaya yardımcı olmak- 
tadır. Bu anlamda çalışanların çevrimiçi faaliyetleri kurumsal iletişim ve itibar için ek bir değere sahiptir. Bu nedenle işletmelerde sosyal medya politikaları aracılığıyla veya bu web sitlerine girişimi engelleyerek bu girişimleri sınırlandırma ve kısıtlama çabaları yanlış yönlendirilmiş görülmektedir (Zoonen, vd., 2014, s.852).

Cao ve arkadaşları (2016) tarafından hazırlanan çalışmada, çalışanların bireysel performanslarının sosyal medya aracilığıyla makul bir şekilde artırılabileceği sonucuna ulaşılmıştır. Şöyle ki ampirik sonuçlar sosyal medyanın çalışanların ağ bağları ile gösterilen sosyal sermayenin oluşumunu destekleyebileceğini, bunun sonucunda bilgi transferini kolaylaştırabilecek ortak vizyon ve güveni ortaya koymaktadır. Paylaşılan vizyon ve bilgi transferi ise iş performansını olumlu yönde etkilemektedir. Her ne kadar ağ bağları ve güven iş performansı üzerinde doğrudan bir etkiye sahip olmasa da, bu etkiye kısmen bilgi aktarımı aracılık etmektedir (Cao, vd., 2016, s.529).

Çetinkaya ve Rashid (2018) tarafindan sosyal medyanın bireysel performans üzerindeki etkisine yönelik yapılan araştırma, sosyal medyanın bireysel performans üzerinde olumlu etkisi olduğu ve örgütsel yapının bu iki değişken arasında aracı bir role sahip olduğu sonucuna varmıştır (Çetinkaya ve Rashid, 2018:15). Zhang ve Venkatesh (2013) sosyal ağların performans üzerindeki etkilerini incelemiş ve sosyal ağların çalışan performansını olumlu yönde etkilediği sonucuna ulaşmıştır (Zhang ve Venkatesh, 2013, s.25). Leftheriotis ve Giannakos (2014) sosyal medyanın iş amaçlı kullanımını araştırmış ve sosyal medyanın çalışanlar için zaman kaybı olmadığını, aynı zamanda çalışanların performansını olumlu yönde etkilediği sonucuna ulaşmışırı (Leftheriotis ve Giannakos, 2014:140). Song ve arkadaşları (2019) iş amaçlı sosyal medya ve sosyal amaçlı sosyal medyanın ekip ve çalışan performansını artırmak için sinerji yaratan tamamlayıcı kaynaklar olduğu sonucuna ulaşmıştır (Song, vd., 2019, s.1).

İşletmeler, çalışanlara yalnızca işe odaklı değil, aynı zamanda sosyalleşme ve eğlenceye yönelik bir kullanım repertuvarı veren sosyal medya gibi yeni teknolojileri giderek daha fazla benimsemektedir (Hassam, vd., 2015, s.65). Hassam ve arkadaşları (2015) sosyal medya kullanım kategorisini sosyal, hedonik ve bilişsel olarak sınıflandırmakta ve bireysel performans üzerindeki etkilerini incelemektedir. Teknolojinin sosyal ve bilişsel kullanımlarının ampirik olarak, dolaylı da olsa çalışanların rutin ve yeni- 
likçi iş performansı üzerinde olumlu etkileri olduğu gösterilmiştir. Teknolojinin hedonik kullanımı, çalışanların rutin performansı üzerinde doğrudan olumlu bir etkiye sahip olmamasına rağmen, sosyal bağların gelişimine olumlu katkı sağladığ etkiye yol açtığ1 gösterilmiştir (Hassam, vd.,2015, s.65).

Hassam ve arkadaşlarının (2015) çalışmasında edindiği önemli bir bulgu yöneticilerin ne tür bir iş performansının onlar için önemli olduğu konusunda güçlü bir fikre sahip olması ve sosyal medya kullanımlarını buna göre yapılandırması gerektiğidir. Yenilikçi ve yaratıcı düşünceyi teşvik etmekle ilgileniyorsa o zaman güçlü bir yapısal sosyal sermaye inşa etmek önemlidir. Bu nedenle teknolojinin sosyal ve bilişsel kullanımını teşvik edebilir ve çok belirgin hedonik etkileşimlerin anlamlı bağları artırmasına izin verebilir. Yöneticilerin amacı rutin çalışma görevlerinin verimliliğini arttırmaksa, herhangi bir hedonik kullanımı engellemeli ve araçsal bağları güçlendirmeyi amaçlayan bazı sosyal ağlarla öncelikle bilişsel kullanıma odaklanmalıdırlar (Hassam, vd., 2015, s.79).

Literatürde işletmelerde sosyal medyanın iş amaçlı ve sosyal amaçlı kullanımını içeren çalışmalar bulunmaktadır. Bu çalışmalar incelendiğinde genel olarak işletmelerde sosyal medya kullanımının çalışanları ve işletmeleri olumlu yönde etkilediği ifade edilmektedir. Söz konusu olumlu yönde etki, sosyal medya kullanımının çalışanların yenilikçi performansları üzerinde de etkili olduğuna işaret etmektedir. Bu nedenle aşağıdaki hipotezler geliştirilmiştir;

- H1: Çalışanların iş amaçlı sosyal medya kullanımı yenilikçi performansı pozitif olarak etkiler.

- H2: Çalışanların sosyal amaçlı sosyal medya kullanımı yenilikçi performansı pozitif olarak etkiler.

\section{Araştırmanın Yöntemi}

Araştırma amacı doğrultusunda yapılan literatür incelemesi kapsamında "işletmelerde sosyal medya kullanımı" ve "yenilikçi performans" ile ilgili anket geliştirilmiştir. Çalışanların iş amaçlı ve sosyal amaçlı sosyal medyayı ne ölçüde kullandıklarını ortaya çıkarmak için iş amaçlı sosyal medya için Zoonen ve arkadaşları (2014), sosyal amaçlı sosyal medya için Zhang ve arkadaşları (2018) tarafından geliştirilen ölçek kullanılmıştır. Ölçekte iş 
amaçlı sosyal medya yedi maddeden, sosyal amaçlı sosyal medya beş maddeden oluşmaktadır. Sosyal medya ölçeği dışındaki ölçek ise yenilikçi performans ölçeğidir. Yenilikçi performans ölçeği Janssen (2004) tarafından geliştirilmiştir. Ölçek dokuz maddeden oluşmaktadır. Kullanılan bu ölçekler 5'li Likert ölçeği çerçevesinde derecelendirilmiştir. Banka çalışanlarindan ankette belirtilen ifadelerin kendilerine ne derece uyduğunu 5'li Likert tipi bir ölçek üzerinde belirtmeleri istenmiştir: (a) Kesinlikle katılmıyorum, (b) Katılmıyorum, (c) Kararsızım, (d)Katılıyorum, (e) Kesinlikle katıllyorum. Ardından toplanan anket verileri SPSS programına aktarılarak değerlendirilmiştir.

Araştırma Ankara ilinde gerçekleştirilmiştir. Araştırmanın evrenini aynı bankanın farklı şubelerinde görev alan 127 banka çalışanı oluşturmaktadır. Bu kapsamda 127 banka çalışanına anket formu verilerek doldurmaları istenmiştir. Üç bölümden oluşan anket formunun ilk bölümünde

katılımcıların yaş, cinsiyet, eğitim, aylık kişisel gelirleri gibi demografik özellikleri ile kaç yıl bankada çalıştıkları, bankadaki görevi, bankada kullandıkları sosyal medya uygulamaları gibi çalıştığı banka ile ilgili bilgileri paylaşmaları istenmektedir. Anketin ikinci bölümünde katılımcıların iş amaçlı ve sosyal amaçlı sosyal medyayı kullanım düzeyleri, üçüncü bölümde ise çalışanların bankadaki yenilikçi performanslarını belirlemeye yönelik bir ölçek bulunmaktadır. Anket formları banka çalışanlarına yüz yüze görüşülerek dağıtılmıştır. Katılımcılara verilen 127 adet anket formundan 111 tanesi doldurulmuş olup, anketlerin doldurulma oranı \%88 olmaktadır.

Araştırmada veri analiz yöntemi olarak nicel veri analiz yöntemi tercih edilmiştir. Araştırmada öncelikle ölçeklerin yapı geçerliliği test edilmek istenmiştir. Faktör analizi, yapı geçerliliğinin incelenmesi amacıyla sık kullanılan yöntemlerden biridir. Faktör analizinde yapı geçerliliğine ilişkin, "bu testlerden elde edilen puanlar, testin ölçtüğünü varsaydığ1 şeyi ölçüyor mu" sorusuna cevap aranmaktadır. Bu açıdan faktör analizi ölçek puanlarının yapı geçerliliğinin değerlendirmesinde önemli bir husus olmaktadır. Bununla birlikte yapı geçerliliğini incelemede amaç, ölçeğin faktör yapısını ortaya çıkarmak ise "Açımlayıcı Faktör Analizi"; amaç daha önce belirlenen ölçek faktör yapısının doğrulanması ise "Doğrulayıcı Faktör Analizi teknikleri kullanılmaktadır (Büyüköztürk, vd. 2016:135). Araştırmada Açımlayıcı Faktör Analizi (AFA) tercih edilerek ölçeklerin 
yapı geçerliliği test edilmek istenmiştir. Bu bağlamda ölçeklerin yapı geçerliliği testi için SPSS 22.0 paket programı kullanılmıştır.

Literatürde AFA'nın yapılabilmesi için bazı kıstaslar bulunmaktadır. Şöyle ki veri kümesinin faktör analizi için uygun olup olmadığın belirlemek için üç yöntem bulunmaktadır. Bu yöntemler; Korelasyon matrisinin oluşturulması, Barlett Testi ve Kaisen Meyer-Olkin (KMO) Testidir (Eşmekaya, 2019, s.27).

KMO testi belirli bir örneklemden elde edilen değişkenlerin oluşturduğu veri yapısının faktör analizi için yeterli olup olmadığını göstermektedir. KMO değerinin 0,60 ve üstünde olması örneklemin faktör analizi için yeterli olacağını göstermektedir. Barlett Küresellik testi ise korelasyon matrisindeki ilişkilerin faktör analizi yapacak ölçüde yeterli olup olmadığını test etmektedir. Bu test sonucun anlamlı olması $(p<0,05)$ değişkenler arası ilişkilerin oluşturduğu matrisin faktör analizi için anlamlı olduğu ve faktör analizi yapılabileceği anlamına gelmektedir (Gürbüz ve Şahin, 2018, s.319).

Açımlayıcı Faktör Analizinde dikkat edilmesi gereken en önemli aşama "faktör sayısına karar verilmesi" aşaması olduğu belirtilebilir. Faktör sayısını belirlemede K1 yöntemi ve Yamaç Birikinti Grafiği kullanılmaktadır. K1 yöntemi fazla sayıda faktör çıkarmasına rağmen Yamaç Birikinti Grafiğinde faktör sayısına karar verme aşamasında baskın faktörleri belirlemeye yönelik grafik oluşturulur. Grafikte kırılma noktası söz konusu olmakta ve faktör sayısı olarak kırılma noktasına kadar olan bileşen sayısı esas alınmaktadır (Eşmekaya, 2019, s.30).

Araştırmada faktör sayısının belirlenmesinde Yamaç Birikinti Grafiği tercih edilmiştir. Faktör sayısının belirlenmesinden sonra önemli bir diğer konu ise faktörlerin döndürülmesidir. Faktör döndürmenin amacı, maddelerin ilgili faktörlerde mümkün olduğunca yüksek, ilgisiz faktörlerde ise mümkün olduğunca düşük yük değerlerinde yüklenmesine olanak tanıyarak, araştırmacıya yorumlama ve karar verme kolaylığı sağlamaktır (Gürbüz ve Şahin, 2018, s.321).

Araştırmada döndürülmüş faktör analizi neticesinde s91 maddesinin çıartılması önerilmiştir.

Atılan değişkenden sonra Açımlayıcı Faktör Analizi tekrar yapılmıştır.

Sosyal bilim araştırmalarında ölçeklerin yapısal geçerliliği KFA ile belirlenirken, ölçeklerin tutarlı ölçüm yapıp yapmadığı ya da ölçek maddele- 
ri arasında tutarlılık olup olmadığının da eş zamanlı olarak belirlenmesi gerekmektedir (Gürbüz ve Şahin, 2018, s.331). Araştırmada ortaya çıkan ölçeğin güvenirliliği Cronbach's Alpa iç tutarlılık katsayısı hesaplanarak ölçülmüştür. Ölçekte tüm alt boyutların güvenirliliği yeterli görülmüştür.

Araştırmada gerekli analizler yapılmadan önce değişkenlerin (iş amaçl1, sosyal amaçlı, yenilikçi performans) her birinin normal dağılım sergileyip sergilemediklerini anlamak adına Shapiro-Wilk normallik testi uygulanmaktadır. Araştırmada Shapiro-Wilk normallik testi sonucunda verilerin normal dağılım göstermediği sonucuna varılmıştır. Veriler normal dağılım göstermediği için analizde parametre dışı istatistik yöntemleri tercih edilmiştir. Analizde Mann-Whitney U testi ve Kruskall

Wallis $\mathrm{H}$ testi kullanılarak sonuçlar elde edilmiştir. Bununla birlikte korelasyon tablosu kullanılarak sosyal medya kullanımı ile yenilikçi performans arasındaki ilişkiye bakılmıştır.

\section{Araştırma Bulguları}

Araştırma bulguları kapsamında katılımcıların demografik ve genel özelliklerine ilişkin veriler analiz edilerek bulgular yorumlanmıştır.

\section{Ölçeklere İlişkin Faktör Analizi}

Faktör analizi, aynı yapıyı ölçen değişkenleri bir araya toplayarak ölçmeyi az sayıda faktör ile açıklamayı amaçlayan bir istatistiksel tekniktir. Açımlayıcı Faktör Analizi, değişkenler arasındaki ilişkilerden yola çıkarak faktör bulmaya yönelik bir işlem iken, Doğrulayıcı Faktör Analizi değişkenler arasındaki ilişkiye dair daha önce saptanan bir hipotezin test edilmesine yönelik bir işlemdir (Büyüköztürk, 2018, s.143). Araştırmada sosyal bilimlerde ölçeğin yapı geçerliliğini incelemede sıklıkla tercih edilen Açımlayıcı Faktör Analizi kullanılmıştır. Katılımcıların iş amaçlı ve sosyal amaçlı sosyal medyayı kullanım düzeyleri ile yenilikçi performans düzeyleri için Açımlayıcı Faktör

Analizi (AFA) yapılmaktadır. 
Tablo 1. Kaiser-Meyer-Olkin (KMO) Örnekleme Yeterliliği Ölçüsü KMO and Bartlett's Test

\begin{tabular}{ccc}
\hline \multicolumn{2}{l}{ Kaiser-Meyer-Olkin Measure of Sampling Adequacy. } &, 858 \\
\hline Bartlett's Test of Sphericity & Approx. Chi-Square & 1574,979 \\
\hline $\mathrm{df}$ & 210 \\
\hline $\mathrm{P}$ &, 000 \\
\hline
\end{tabular}

Tablo 1 incelendiğinde örneklemin yeterli olduğu sonucuna varılmaktadır. Şöyle ki, KMO'nun

değeri .50 ile .59 arasında zayıf, .60 ile .69 arasında orta, .70 ile .79 arasında iyi, .80 ile .89 arasında çok iyi ve .90 ve üzeri ise mükemmel kabul edilmektedir (George ve Mallery, 2001'den akt. Yaratan, 2017, s.230-231). KMO değeri (.858) mükemmel olarak kabul edilmektedir. Bir başka değişle Açımlayıcı Faktör Analizinde KMO testine göre elde edilen verilerin faktör analizi için uygun ve denek sayısının yeterli olduğu söylenebilir. $(\mathrm{p}<0,05)$

Bartlett's Test of Sphericity maddeler arasinda korelasyon olup olmadığını test etmektedir. Bu test için boş hipotez; "maddelerin korelasyon matrisi ile birim matrisi arasında hiç fark yoktur" şeklinde ifade edilmektedir (George ve Mallery, 2001'den akt. Yaratan, 2017, s.231).

Tablo 2. Açıklanmış Toplam Varyans Çizelgesi

\begin{tabular}{|c|c|c|c|c|c|c|c|c|c|}
\hline \multirow{2}{*}{ 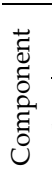 } & \multicolumn{3}{|c|}{ Initial Eigenvalues } & \multicolumn{3}{|c|}{$\begin{array}{l}\text { Extraction Sums of } \\
\text { Squared Loadings }\end{array}$} & \multicolumn{3}{|c|}{$\begin{array}{l}\begin{array}{l}\text { Rotation Sums of } \\
\text { Squared Loadings }\end{array} \\
\end{array}$} \\
\hline & Total & $\begin{array}{l}\% \text { of } \\
\text { Variance }\end{array}$ & $\begin{array}{l}\text { Cumulative } \\
\%\end{array}$ & Total & $\begin{array}{l}\% \text { of } \\
\text { Variance }\end{array}$ & $\begin{array}{l}\text { Cumulative } \\
\%\end{array}$ & Total & $\begin{array}{l}\% \text { of } \\
\text { Variance }\end{array}$ & $\begin{array}{l}\text { Cumulative } \\
\%\end{array}$ \\
\hline 1 & 7,289 & 34,711 & 34,711 & 7,289 & 34,711 & 34,711 & 6,494 & 30,926 & 30,926 \\
\hline 2 & 4,762 & 22,676 & 57,388 & 4,762 & 22,676 & 57,388 & 3,812 & 18,150 & 49,076 \\
\hline 3 & 1,706 & 8,126 & 65,514 & 1,706 & 8,126 & 65,514 & 3,452 & 16,437 & 65,514 \\
\hline
\end{tabular}

Tablo 2'de de görüldüğü üzere Eigen value değeri (başlangıç öz değerleri) 1 den büyük olan 3 faktörden oluştuğu görülmektedir.

Açımlayıcı faktör analizinde alt boyutların sayısını belirlemek için çeşitli yöntemler kullanılmaktadır. Bu çalışmada alt boyut sayısını belirlemek için yamaç-birikinti grafiği kullanılmaktadır. Grafikte dikey eksen özdeğerleri, yatay eksen ise bileşenleri göstermektedir. 


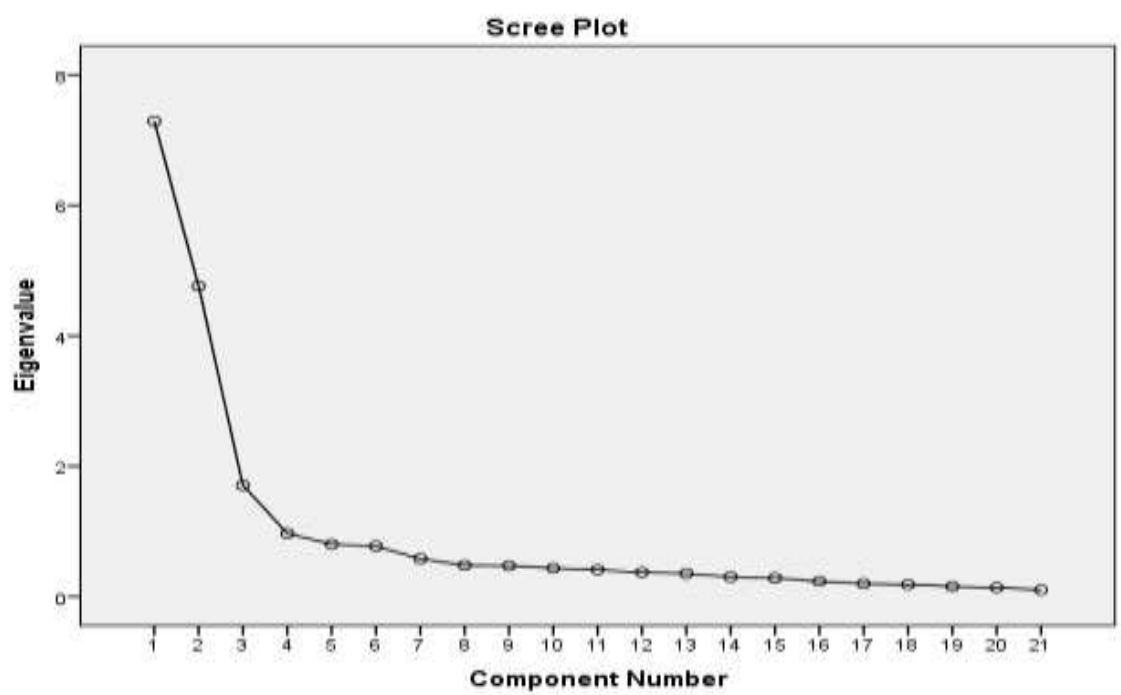

Şekil 1. Bileşenlerin Yamaç-Birikinti Grafiği

Bu yöntemde korelasyon matrisindeki özdeğerler hesaplanmakta, Şekil 1. incelendiğinde korelasyon matrisinin 21 satırı bulunmaktadır. 21 faktörün tümü yatay çizgi üzerinde sıralanmakta, dikey kısımda ise ölçeğin alt boyutu olarak belirlenecek faktörler sıralanmaktadır. Dolayısıyla Şekil 1'de dikey kısım üzerinde faktör (bileşen) sayısı üçtür. Dolayısıyla ölçeğin sadece 3 alt boyutunun olduğu kanıtlanmıştır. Korelasyon matrisi ile birim matrisinin birbirine eşit olması durumunda herhangi iki madde arasındaki korelasyon sifıra eşit olmaktadır (Yaratan, 2017, s.232). Barlett's Test of Sphericity anlamlılık düzeyini .000 olarak belirttiği için boş hipotez reddedilir ve maddeler arasında korelasyon olduğu sonucuna varılır, x2 (210)= 1574,979, $\mathrm{p}=.000<.001$. Barlett's Test of Sphericity anlamlı çıkmasaydı faktör analizi yapilamazdi.

Faktör analizinin faktör çıarımı ve faktör döndürme olmak üzere iki aşaması bulunmaktadır. Faktör çıkarımı analizinin neticesinde kaç faktör (bileşen) olacağı saptanmaktadır. Şekil 1'de dikey kısım üzerinde faktör sayısı üçtür. Dolayısıyla ölçeğin sadece üç alt boyutunun olduğu kanitlanmıştır. Yaratan'a (2017) göre faktör analizinin ikinci aşaması olan faktör döndürmenin amacl; faktör uzayını temsil eden eksenleri döndürerek maddeleri temsil eden değişkenlerin bir faktördeki yükü artarken diğer faktör- 
lerdeki yüklerinin azalmasını sağlamak ve böylece faktörleri daha belirgin ve yorumlanabilir hale getirmektir (Yaratan, 2017, s. 234).

İki tür eksen döndürme yöntemi bulunmaktadır. Bunlar; dik döndürme ve eğik döndürme yöntemleridir. Dik döndürme yöntemi faktörler arasında ilişki yoksa söz konusu iken, sosyal araştırmalarda faktörler arasında korelasyon olma olasılığı yüksek olduğu için eğik döndürme yaygın olarak kullanılmaktadır (Yaratan, 2017, s.234).

Tablo 3'de madde değişkenlerinin faktör yükleri yer almaktadır.

Tablo 3. Döndürülmüş Bileşen Matrisi Rotated Component Matrix ${ }^{a}$

\begin{tabular}{|c|c|c|c|}
\hline \multirow[b]{2}{*}{1} & \multicolumn{3}{|c|}{ Component } \\
\hline & $\overline{2}$ & 3 & \\
\hline s102 & 875 & & \\
\hline s105 & ,868 & & \\
\hline s106 & 862 & & \\
\hline s103 & 859 & & \\
\hline s104 &, 848 & & \\
\hline s107 & 835 & & \\
\hline s109 & ,826 & & \\
\hline s101 & 824 & & \\
\hline s108 & ,771 & & \\
\hline s94 & & 829 & \\
\hline s931 & & 810 & \\
\hline s92 & & 804 & \\
\hline s95 & & 752 & \\
\hline$s 82$ & & ,736 & \\
\hline s91 & -070 & 333 &, 313 \\
\hline $\mathrm{s} 83$ & & & , 880 \\
\hline 884 & & &, 836 \\
\hline 881 & & & ,687 \\
\hline$s 85$ & & & ,669 \\
\hline 886 & & & ,621 \\
\hline $\mathrm{s} 87$ & & & ,564 \\
\hline
\end{tabular}

Tablo 3 incelendiğinde, örneğin s102 değişkeninin faktör 1'deki yükü .875, s94 değişkeninin faktör 2' deki yükü .829 olduğu görülmektedir. Tablo 3 'de bazı maddelerin değişkenlerinin problemli olduğu görülmektedir. Şöyle ki, faktör yükleri incelendiğinde s91 maddesinin faktör 2 ve faktör 3 de yakın ağırlıkla temsil edildiği görülmektedir. Bu nedenle s91 maddesinin çıkartılması önerilmektedir. 
Ayrıca s82 sorusunun s9 grubunda yer alması önerilmektedir. Her atılan değişkenden sonra faktör analizi tekrar edildiğinden dolayı, s91 sorusu çıkartılarak açıklayıcı faktör analizi (AFA) tekrar yapılmaktadır.

Tablo 4. 2. Adım AFA Sonuçları-KMO ve Bartlett's Test

\begin{tabular}{ll}
\hline \multicolumn{2}{c}{ KMO and Bartlett's Test } \\
\hline Kaiser-Meyer-Olkin Measure of Sampling Adequacy. &, 860 \\
\hline Bartlett's Test of Sphericity & Approx. Chi-Square \\
\cline { 2 - 2 } & 1544,283 \\
\hline & $\mathrm{df}$ \\
\cline { 2 - 2 } & $\mathrm{P}$ \\
\hline
\end{tabular}

2.adımda $\mathrm{KMO}$ endeksine göre verilerin ve örneklemin yeterli olduğu görülmektedir. $(\mathrm{p}<0,05)$.

Tablo 4'de görüldüğü üzere KMO değeri .860 ve Bartlett's Test of Sphericity de anlamlıdır, x2 (190)=1544.283, p=.000<.001.

Tablo 5. 2. Adım AFA Sonuçları-Açıklanmış Toplam Varyans Çizelgesi

\begin{tabular}{|c|c|c|c|c|c|c|c|c|c|}
\hline \multirow[b]{2}{*}{$\begin{array}{l}\text { Compo } \\
\text { nent }\end{array}$} & \multicolumn{3}{|c|}{ Initial Eigenvalues } & \multicolumn{3}{|c|}{$\begin{array}{l}\text { Extraction Sums of } \\
\text { Squared Loadings }\end{array}$} & \multicolumn{2}{|c|}{$\begin{array}{l}\text { Rotation Sums of } \\
\text { Squared Loadings }\end{array}$} & \multirow[b]{2}{*}{$\begin{array}{l}\mathrm{Cu} \\
\text { mulative } \\
\%\end{array}$} \\
\hline & Total & $\begin{array}{c}\text { \%of } \\
\text { Variance }\end{array}$ & $\begin{array}{l}\text { Cumulative } \\
\%\end{array}$ & eTotal & $\begin{array}{c}\text { \%Of } \\
\text { Variance }\end{array}$ & $\begin{array}{l}\text { Cumulative } \\
\%\end{array}$ & eTotal & $\begin{array}{l}\% \text { of } \\
\text { Variance }\end{array}$ & \\
\hline 1 & 7,257 & 36,285 & 36,285 & 7,257 & 36,285 & 36,285 & 6,465 & 32,323 & 32,323 \\
\hline 2 & 4,616 & 23,08 & 59,365 & 4,616 & 23,080 & 59,365 & 3,718 & 18,591 & 50,913 \\
\hline 3 & 1,706 & 8,531 & 67,896 & 1,706 & 8,531 & 67,896 & 3,397 & 16,983 & 67,896 \\
\hline
\end{tabular}

Tablo 5'de görüldüğü üzere Eigen value değeri (başlangıç öz değerleri) 1 den büyük olan 3 faktörlü bir yapının oluştuğu görülmektedir. Bu yapının varyansın \%67,8 ini açıkladığı görülmektedir. 


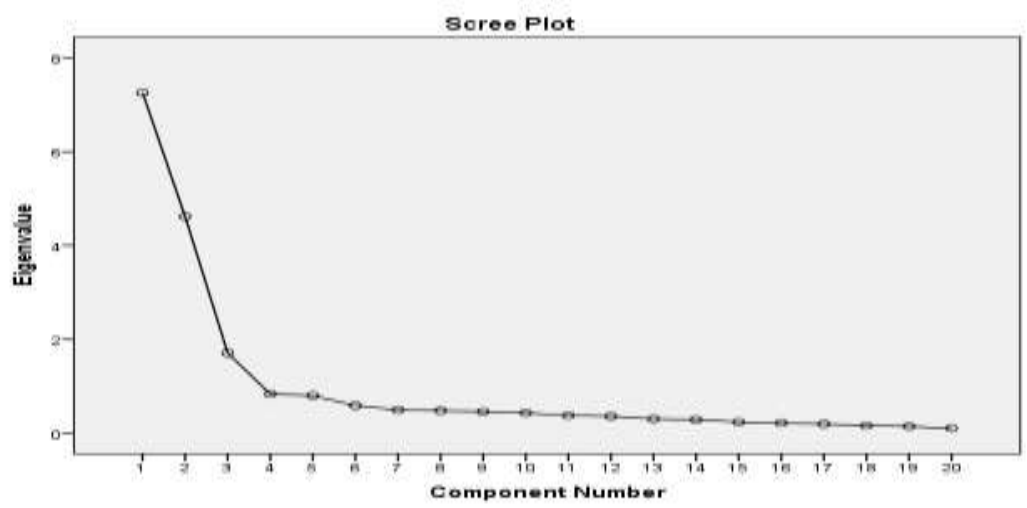

Şekil 2. 2. Adım AFA Sonuçları-Bileşenlerin Yamaç-Birikinti Grafiği

Şekil 2'de yamaç birikim çizgesindeki eğrinin dikey kısmında diğerlerinden ayrılmış üç adet faktör olduğu görülmektedir.

Tablo 6. Döndürülmüş Bileşen Matrisi

\begin{tabular}{|c|c|c|c|}
\hline \multirow[b]{3}{*}{ s102 } & \multicolumn{3}{|c|}{ Component } \\
\hline & 1 & 2 & 3 \\
\hline &, 876 & & \\
\hline$\underline{s 105}$ &, 868 & & \\
\hline$\underline{s 106}$ &, 863 & & \\
\hline$\underline{s 103}$ &, 856 & & \\
\hline s104 & 847 & & \\
\hline$\underline{\mathrm{s} 107}$ & 833 & & \\
\hline$\underline{s 109}$ &, 826 & & \\
\hline$\underline{s 101}$ & 823 & & \\
\hline $\mathrm{s} 108$ &, 769 & & \\
\hline s94 & &, 823 & \\
\hline s93 & &, 810 & \\
\hline s92 & &, 805 & \\
\hline$\underline{\text { s95 }}$ & & ,758 & \\
\hline$\underline{s 82}$ & & ,741 & \\
\hline$\underline{\mathrm{s} 83}$ & & &, 878 \\
\hline $\mathrm{s} 84$ & & & ,837 \\
\hline$\underline{\mathrm{s} 81}$ & & & ,690 \\
\hline$\underline{\mathrm{s} 85}$ & & & ,683 \\
\hline$\underline{s 86}$ & & & ,619 \\
\hline s87 & & &, 571 \\
\hline
\end{tabular}


Tablo 6 incelendiğinde döndürülmüş bileşen matrisinde üç faktörün yükleri görülmektedir. Faktör yükleri incelendiğinde ağırlıkların 0,5 ve üstünde olduğu görülmektedir. Üç faktörlü bir yapı olduğu söylenebilir. Bu yapıda boyutları şu şekilde tanımlayabiliriz;

- Boyut 1: İşamaçli (s81, s83, s84, s85, s86, s87)

- Boyut 2: Sosyal amaçlı (s82, s92, s93, s94, s95)

- Boyut 3: Yenilikçi (s101, s102, s103, s104, s105, s106, s107, s108, s109)

Ölçekten s82, s9 grubunda yer almakta ve s91 sorusu ölçekten atılmıştır. Sonuçta 20 maddeli ve üç alt boyutu olan bir ölçek olarak kalmıştır. Ortaya çıkan ölçeğin güvenilirliğini ölçmek için

Cronbach's Alpa iç tutarlılık katsayısı hesaplanmaktadır.

\section{Güvenilirlik Testi}

Ölçümlerin güvenilirliğini belirlemede Cronbach's Alpha yöntemi kullanılmaktadır.

\section{Tablo 7. Cronbach's Alpha Katsayısı}

\begin{tabular}{lll}
\hline & Cronbach's Alpha & Madde sayısı \\
\hline İş amaçlı &, 859 & 6 \\
\hline Sosyal amaçlı &, 878 & 5 \\
\hline Yenilikçi &, 949 & 9 \\
\hline
\end{tabular}

Her boyutun güvenirlik katsayıları tabloda görülmektedir. Alpha değerlerinin 0,7 den yüksek olduğu görülmektedir. Bu açıdan tüm alt boyutların güvenirliliği yeterli görülmektedir.

\section{Demografik ve Genel Bulgular}

Aşağıdaki tablolarda demografik değişkenlerin frekansları alınarak tablo haline getirilmiştir.

Tablo 8. Çalışanların Yaş, Aylık Gelir ve İşletmedeki Çalışma Yılı

\begin{tabular}{lllllll}
\hline & $\mathrm{N}$ & Mean & Median & Min & Max & Ss \\
\cline { 2 - 7 } Yaş & 111 & 37 & 36 & 21 & 55 & 7 \\
Aylık gelir & 111 & 4769 & 5000 & 21001,00 & 14000 & 17907,28 \\
İşletmedeki çalışma yılı & 111 & 12,17 & 10,00 & & 30,00 & \\
\hline
\end{tabular}


Banka çalışanlarının yaş, aylık gelir ve bankadaki çalışma yılı ile ilgili tanımlayıcı istatistikler Tablo 8'de gösterilmektedir. 111 banka çalışanının yaşları en düşük 21 en yüksek 55 arasında değişmektedir. Ortalama değer mean olarak gösterilmekte ve $37^{\prime}$ dir. Ss standart sapma değeridir.

Verilerin ortalamadan ne kadar saptığını gösteren ölçü birimidir. Bu veri setinde standart sapma 7'dir. Yani verilerimiz ortalama +- standart sapma yani $37+/$ - kadar bir sapma göstermektedir.

Tablo 9. Çalışanlarn Cinsiyet ve Eğitim Durumu

\begin{tabular}{llll}
\hline & & $\mathbf{n}$ & \% \\
\hline \multirow{3}{*}{ Cinsiyet } & Kadin & 55 & 50 \\
& Erkek & 55 & 50 \\
& Total & 110 & 100 \\
\hline \multirow{4}{*}{ Eğitim durumu } & Lise & 12 & 10,8 \\
& Ön lisans & 4 & 3,6 \\
& Lisans & 81 & 73 \\
& Y.Lisans & 14 & 12,6 \\
& Total & 111 & 100 \\
\hline
\end{tabular}

Tablo 9'da çalışanların cinsiyet ve eğitim durumlarına ilişkin bilgiler yer almaktadır. 111 çalışanın 56'sını erkekler, 55'ini ise kadınlar oluşturmaktadır. Çalışanların eğitim durumuna bakıldığında; 12'si lise, 4'ü önlisans, 81 'i lisans ve 14 'ü yüksek lisans mezunudur.

Tablo 10. Çalışanların Bankada Kullandıkları Sosyal Medya Uygulamaları

\begin{tabular}{lll}
\hline & $\mathrm{n}$ & $\%$ \\
\hline Whatsapp & 92 & 82,9 \\
Twiter & 9 & 8,1 \\
Facebook & 16 & 14,4 \\
Youtube & 17 & 15,3 \\
Linkedin & 3 & 2,7 \\
İnstagram & 22 & 19,8 \\
Foursquare & 1 & 0,9 \\
Pinterest & 1 & 0,9 \\
\hline
\end{tabular}

Çalışanların bankada kullandıkları sosyal medya uygulamaları Tablo 10 'da gösterilmektedir.

Çalışanların çoğunlukla whatsapp'ı tercih ettikleri görülmektedir. 
Tablo 11. Sosyal Medya ve Yenilikçi Performans

\begin{tabular}{lllllll}
\hline & n & Mean & \multicolumn{2}{l}{ Median Minimum } & Maximum & ss \\
\hline İş Amaçlı SM & 111 & 17,68 & 18,00 & 6,00 & 30,00 & 5,78 \\
\hline Sosyal Amaçlı SM & 111 & 11,35 & 11,00 & 5,00 & 25,00 & 5,01 \\
\hline Yenilikçi Performans & 111 & 34,76 & 36,00 & 9,00 & 45,00 & 6,40 \\
\hline
\end{tabular}

Tablo 11'de çalışanların iş amaçlı ve sosyal amaçlı sosyal medya kullanım ölçüsü ile çalışanların kendilerini yenilikçi görme ölçüleri yer almaktadir.

Tablo 12. Sosyal Medya ve Yenilikçi Performans (Yaş-Aylık Gelir)

\begin{tabular}{lllll}
\hline \multirow{2}{*}{ Yenilikçi Performans } & & Yaş & Aylık gelir & İşletmedeki çalışma yılı \\
\cline { 2 - 5 } & $\mathrm{r}$ &, 27 &, 122 &,- 007 \\
& $\mathrm{p}$ &, 776 &, 203 &, 942 \\
& $\mathrm{~N}$ & 111 & 111 & 111 \\
\hline Sosyal Amaçlı SM & $\mathrm{r}$ &,- 062 &, $204^{*}$ &,- 138 \\
& $\mathrm{p}$ &, 521 &, 032 &, 148 \\
& $\mathrm{~N}$ & 111 & 111 & 111 \\
\hline İş Amaçlı SM & $\mathrm{r}$ &,- 130 &, 037 &,$- 211^{*}$ \\
& $\mathrm{p}$ &, 173 &, 699 &, 026 \\
& $\mathrm{~N}$ & 111 & 111 & 111 \\
\hline
\end{tabular}

Tablo 12 incelendiğinde aylık gelir ile sosyal amaçlı kullanma puanı arasında anlamlı ve aynı yönlü ancak düşük dereceli bir ilişki görülmektedir. $(\mathrm{p}<0,05 ; \mathrm{r}=0,204)$ Aylık gelir arttıkça sosyal amaçlı kullanma puanı artmaktadir.

İşletmedeki çalışma yılı ile iş amaçlı sosyal medyayı kullanma durumları arasında anlamlı, ters yönlü ancak düşük bir ilişki görülmektedir. $(\mathrm{p}<0,05 ; \mathrm{r}=-$ $0,211)$ İşletmedeki çalışma yılı arttıkça sosyal medyayı iş amaçlı kullanma puanları azalmaktadır.

Araştırma için gerekli analizler yapılmadan önce "iş amaçlı", "sosyal amaçlı" ve "yenilikçi performans" değişkenlerinin her birinin normal dağılım sergileyip sergilemediğini anlamak için Shapiro-Wilk normallik testi uygulanmaktadır. Bu araştırma için anlamlılık düzeyi 0,05 olarak belirlenmektedir. 


\section{Normallik Testi}

Tablo 13. Shapiro-Wilk Normallik Testi

\begin{tabular}{|c|c|c|c|c|c|}
\hline \multicolumn{6}{|c|}{ Tests of Normality } \\
\hline & \multicolumn{3}{|c|}{ Kolmogorov Smirnov ${ }^{a}$} & \multicolumn{2}{|c|}{ Shapiro-Wilk } \\
\hline & Statistic & df & Sig. & Statistic & df Sig. \\
\hline İş Amaçlı SM & ,107 & 111 &, 003 & ,973 & 111,025 \\
\hline Sosyal Amaçlı SM & , 105 & 111 & ,005 & ,935 & 111,000 \\
\hline Yenilikçi P. & ,183 & 111 &, 000 &, 835 & 111,000 \\
\hline
\end{tabular}

Tablo 14. Shapiro-Wilk Normallik Testi (Cinsiyet Demografik Değişkeni)

\begin{tabular}{|c|c|c|c|c|c|c|c|}
\hline \multirow[t]{3}{*}{ Cinsiyet } & & \multicolumn{6}{|c|}{ Tests of Normality } \\
\hline & & \multicolumn{3}{|c|}{ Kolmogorov-Smirnova } & \multicolumn{2}{|c|}{ Shapiro-Wilk } & \\
\hline & & Statistic & df & Sig. & Statistic & df & Sig. \\
\hline \multirow[b]{2}{*}{ İş Amaçlı SM } & Kadın & 087 & 55 & $200^{*}$ & ,968 & 55 & 147 \\
\hline & Erkek & 124 & 55 & 033 & 974 & 55 & 283 \\
\hline \multirow{2}{*}{$\begin{array}{l}\text { Sosyal Amaçlı } \\
\text { SM }\end{array}$} & Kadın & 123 & 55 & 038 & ,935 & 55 & ,005 \\
\hline & Erkek & 109 & 55 & 156 & ,928 & 55 & ,003 \\
\hline Yenilikçi & Kadın & 164 & 55 & ,001 &, 870 & 55 &, 000 \\
\hline Performans & Erkek & 209 & 55 & 000 & 810 & 55 & 000 \\
\hline
\end{tabular}

*. This is a lower bound of the true significance . a. Lilliefors Significance Correction

"İş amaçlı", "sosyal amaçlı" ve "yenilikçi performans" değişkenleri çalışanların cinsiyeti açısından bir farklılık oluşturmakta mıdır? Bunun cevabı için analiz öncesinde her kategorinin normal dağılım sergileyip sergilemediğini görmek adına Shapiro-Wilk normallik testi uygulanmaktadır.

Tablo 15. Shapiro-Wilk Normallik Testi (Ĕ̈itim Demografik Değişkeni

\begin{tabular}{|c|c|c|c|c|c|c|c|}
\hline \multirow[t]{3}{*}{ Cinsiyet } & & \multicolumn{6}{|c|}{ Tests of Normality } \\
\hline & & \multicolumn{3}{|c|}{ Kolmogorov-Smirnov ${ }^{a}$} & \multicolumn{2}{|c|}{ Shapiro-Wilk } & \multirow[b]{2}{*}{ Sig. } \\
\hline & & Statistic & df & Sig. & Statistic & df & \\
\hline \multirow{3}{*}{ İş Amaçlı SM } & Ön Lisans ve altı & 129 & 16 & $200^{*}$ & ,963 & 16 & 714 \\
\hline & Lisans & ,097 & 81 & ,056 & ,969 & 81 & 047 \\
\hline & Y. Lisans & ,208 & 14 & 103 &, 860 & 14 & 0,03 \\
\hline Sosyal Amaçlı & Ön Lisans ve altı & 169 & 16 &, $200^{*}$ & ,888 & 16 & ,053 \\
\hline \multirow[t]{2}{*}{ SM } & Lisans & 105 & 81 & ,027 & ,940 & 81 & ,001 \\
\hline & Y. Lisans & ,212 & 14 & ,089 & ,889 & 14 & ,077 \\
\hline Yenilikçi & Ön Lisans ve altı & ,124 & 16 &, $200^{*}$ & ,973 & 16 & 882 \\
\hline \multirow[t]{2}{*}{ Performans } & Lisans & ,206 & 81 &, 000 & ,767 & 81 &, 000 \\
\hline & Y. Lisans & ,174 & 14 &, $200^{*}$ & ,934 & 14 & ,346 \\
\hline
\end{tabular}

*. This is a lower bound of the true significance. a. Lilliefors Significance Correction 
Tablo $15^{\prime}$ de ise eğitim demografik değişkeni bakımından Shapiro-Wilk normallik testi uygulanmaktadır.

Tablolar incelendiğinde verilerimizin normal dağılım sergilemedikleri görülmektedir.

Verilerimizin dağılımı normal dağılıma uymadığından parametre dışı istatistik yöntemlerinin kullanılması gerekmektedir. Analizde T-testinin karşıllı̆ı olan Mann-Whitney U Testi ve Tek Yönlü Anova testinin karşllı̆̆ olan Kruskall-Wallis H Testi uygulanarak sonuçlar elde edilmiştir. Bağımsız örneklemler t-testi iki bağımsız örneklemden aynı değişken için toplanan verilerin ortalamaları arasındaki farkı tespit etmek için kullanılmaktadır. Ancak bu testin yapılabilmesi için iki bağımsız örneklemin temsil ettiği evrenlerle ilgili üç varsayımda bulunulması gerekmektedir. Eğer bu varsayımlardan herhangi biri yapılmazsa bağımsız örneklemler t-testi yerine non-parametrik bir test olan Man-Whitney U Testi uygulanmaktadır

Tablo 16. Mann-Whitney U Testi

Mann-Whitney U Testi

\begin{tabular}{|c|c|c|c|c|c|c|c|c|c|c|}
\hline & & $\bar{n}$ & Mean & Median & Min & Max. & ss & Sira Ort & $\mathrm{U}$ & $\mathbf{P}$ \\
\hline İşs & Kadın & 55 & 18,07 & 19,00 & 6,00 & 29,00 & 5,69 & 57,4 & & \\
\hline \multirow[t]{2}{*}{ Amaçlı SM } & Erkek & 55 & 17,44 & 18,00 & 6,00 & 30,00 & 5,83 & 53,6 & 1407 &, 527 \\
\hline & Total & 110 & 17,75 & 18,00 & 6,00 & 30,00 & 5,74 & & & \\
\hline Sosyal & Kadın & 55 & 11,05 & 11,00 & 5,00 & 22,00 & 4,59 & 54,1 & & \\
\hline \multirow[t]{2}{*}{ Amaçlı SM } & Erkek & 55 & 11,71 & 11,00 & 5,00 & 25,00 & 5,44 & 56,9 & 1434,5 & ,639 \\
\hline & Total & 110 & 11,38 & 11,00 & 5,00 & 25,00 & 5,02 & & & \\
\hline Yenilikçi & Kadın & 55 & 35,22 & 36,00 & 12,00 & 45,00 & 5,95 & 58,6 & & \\
\hline \multirow[t]{2}{*}{ Performans } & Erkek & 55 & 34,27 & 35,00 & 9,00 & 45,00 & 6,90 & 52,4 & 1341,5 & ,304 \\
\hline & Total & 110 & 34,75 & 36,00 & 9,00 & 45,00 & 6,43 & & & \\
\hline
\end{tabular}

Cinsiyetler arasında puanlar açısından anlamlı bir farklılık görülmemektedir.(p>0,05)

İstatistiksel olarak anlamlı olmamakla birlikte iş amaçlı ve yenilikçi puanları kadınlarda daha yüksek görülmektedir.

Kruskall-Wallis H Testi bir bağımlı ve bir de bağımsız değişkeni olan araştırmalarda

kullanılmaktadır. Bağımsız değişkenin değerleri sınıflandırma ölçeği ile elde edilmektedir. Eğer iki kategori söz konusu ise Mann-Whitney U Testi 
kullanılmakta, ama eğer bağımsız değişkenin kategorileri ikiden fazla ise Kruskal-Wallis H Testi kullanılmaktadır (Yaratan, 2017, s.204).

Tablo 17. Kruskall-Wallis H testi

\begin{tabular}{|c|c|c|c|c|c|c|c|c|c|c|c|}
\hline \multirow{6}{*}{ 苞 } & \multirow{6}{*}{$\begin{array}{l}\text { Ön lisans ve alt } \\
\text { Lisans } \\
\text { Y.Lisans } \\
\text { Total }\end{array}$} & \multicolumn{6}{|c|}{ Eğitim durumu } & \multicolumn{4}{|c|}{ Kruskall-Wallis $\mathrm{H}$ testi } \\
\hline & & $\mathbf{n}$ & \multirow{2}{*}{$\begin{array}{l}\text { Mean } \\
15,81\end{array}$} & \multirow{2}{*}{$\begin{array}{l}\begin{array}{l}\text { Me- } \\
\text { dian }\end{array} \\
15,50\end{array}$} & \multirow{2}{*}{$\begin{array}{l}\text { Min } \\
9,00\end{array}$} & \multirow{2}{*}{$\begin{array}{l}\text { Max } \\
23,00\end{array}$} & \multirow{2}{*}{$\begin{array}{l}\text { ss } \\
4,23\end{array}$} & \multirow{2}{*}{$\begin{array}{l}\text { Sira } \\
\text { Ort. } \\
43,47\end{array}$} & \multirow[t]{2}{*}{ H } & \multirow[t]{2}{*}{$\mathrm{p}$} & \multirow{2}{*}{$\begin{array}{l}\begin{array}{l}\text { İkili } \\
\text { karşılatırma }\end{array} \\
3-1\end{array}$} \\
\hline & & $\overline{16}$ & & & & & & & & & \\
\hline & & 81 & 17,59 & 18,00 & 6,00 & 30,00 & 6,13 & 55,67 & \multirow{3}{*}{6,01} & \multirow{3}{*}{,049 } & $3-2$ \\
\hline & & 14 & 20,29 & 21,00 & 9,00 & 25,00 & 4,36 & 72,21 & & & \\
\hline & & 111 & 17,68 & 18,00 & 6,00 & 30,00 & 5,78 & & & & \\
\hline \multirow{4}{*}{ 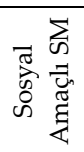 } & Ön lisans ve altı & 16 & 9,00 & 9,50 & 5,00 & 17,00 & 3,76 & 41,16 & \multirow{4}{*}{7,90} & \multirow{4}{*}{,018 } & $3-1$ \\
\hline & Lisans & 81 & 11,30 & 11,00 & 5,00 & 25,00 & 4,95 & 55,77 & & & $3-2$ \\
\hline & Y.Lisans & 14 & 14,36 & 12,50 & 5,00 & 21,00 & 5,34 & 74,29 & & & \\
\hline & Total & 111 & 11,35 & 11,00 & 5,00 & 25,00 & 5,01 & & & & \\
\hline \multirow{4}{*}{ 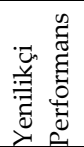 } & Ön lisans ve alt1 & 16 & 31,75 & 33,00 & 19,00 & 45,00 & 7,12 & 38,22 & \multirow{4}{*}{5,70} & \multirow{4}{*}{,055 } & \multirow{4}{*}{ - } \\
\hline & Lisans & 81 & 35,19 & 36,00 & 9,00 & 45,00 & 6,52 & 58,86 & & & \\
\hline & Y.Lisans & 14 & 35,71 & 36,00 & 30,00 & 42,00 & 3,71 & 59,75 & & & \\
\hline & Total & 111 & 34,76 & 36,00 & 9,00 & 45,00 & 6,40 & & & & \\
\hline
\end{tabular}

İşa amaçlı ve sosyal amaçlı puanlarının y.lisans grubunda anlamlı derecede yüksek görülmektedir.(p<0,05) Eğitim durumu arttıkça puanlarda artış olduğu görülmektedir.

Yenilikçi puanı açısından gruplar arasında anlamlı bir farklılık görülmemektedir. $(p>0,05)$ İstatistiksel olarak anlamlı olmamakla birlikte ön lisans ve altı grubunda puanların daha düşük olduğu görülmektedir.

Çalışmanın amacına uygun olarak iş amaçlı ve sosyal amaçlı sosyal medya kullanım düzeyleri ile çalışanların yenilikçi performansı arasındaki ilişkiye korelasyon tablosu kullanılarak bakılmaktadır.

\section{Değişkenler Arasındaki İlişkiler}

İşa amaçlı sosyal medya, sosyal amaçlı sosyal medya ve yenilikçi performans arasındaki ilişki korelasyon tablosu ile belirlenmektedir.

Tablo 18. Korelasyon Tablosu

\begin{tabular}{lllll}
\hline \multicolumn{1}{l}{ Correlations (Korelasyon) } & & & \\
\cline { 3 - 5 } Yenilikçi & $\mathrm{R}$ (İlişki) & İs amaçl1 & Sosyal amaçl1 & Yenilikçi P \\
\cline { 3 - 5 } Performans & $\mathrm{P}$ (significance) &, 013 &, 156 & 1 \\
& $\mathrm{~N}$ & 111 &, 103 & \\
& & & 111 & 111 \\
\hline
\end{tabular}


Tablo 18 incelendiğinde iş amaçlı sosyal medya puanı arttıkça yenilikçi performans puanı da artmaktadır. $(\mathrm{p}<0,05 \mathrm{r}=0,235)$ İlişki anlamlı ancak düşük olarak görülmektedir.

Sosyal amaçlı sosyal medya kullanımı ile yenilikçi performans arasındaki ilişkiye bakıldığında ise iki değişken arasında anlamlı bir ilişki görülmemektedir $(\mathrm{p}=0.103>0,05)$.

\section{Sonuç}

Günümüz işletmelerinin örgütsel amaçlarını gerçekleştirmede sosyal medya araçlarına giderek daha fazla başvurdukları görülmektedir. Bu çalışmanın temel amacı, çalışanların işletmelerde iş amaçlı ve sosyal amaçlı sosyal medya kullanımlarının çalışanların yenilikçi performans üzerindeki etki gücünü tespit edebilmektedir. İş amaçlı sosyal medya kullanımı çalışanların iş arkadaşlarıyla kolaylıkla bilgi paylaşımı sağlamasına imkan tanımakta, böylelikle çalışanlar arasında hızlı bilgi akışı sağlanmakta ve çalışanların işle ilgili konularda fikir edinmelerini kolaylaşmaktadır. Nitekim etkili iletişim ve erişilebilirlik ile iş hedeflerine ulaşılması kolaylaşmakta ve çalışanların katılım duygularına katkı sağlanılmaktadır. Bu nedenle çoğu işletmenin sosyal medya kullanımını stratejik yönetim, örgütsel iletişim ve halkla ilişkileri ile uyumlu hale getirdiği görülmektedir.

İşletmelerde iş amaçlı sosyal medyanın yanı sıra sosyal amaçlı sosyal medya da yaygın bir şekilde kullanılmaktadır. Sosyal amaçlı sosyal medya kullanımına çalışanların işteyken işe ara vermesi, iş arkadaşlarıyla çalışma sonrası yapılmak üzere sosyal etkinlikler düzenlemeleri, işletme içerisinden arkadaş edinmesi, arkadaşlarıyla sohbet etmesi gibi örnekler verilebilir. Akademik yazında yapılan araştırmalarda işletmelerdeki iş amaçlı ve sosyal amaçlı sosyal medya kullanımlarına bakıldığında sosyal medyanın çoğunlukla işyerinde kesintilere neden olabileceği şeklinde hüküm süren anlayışın aksine çalışanlar arasında hızlı ve etkili iletişimi sağlayarak örgütsel iletişimin kalitesini artırdığı sonucuna varılmaktadır.

Örgütsel performans ve rekabet edilebilirlik büyük ölçüde çalışan performansına göre belirlenmektedir. Birçok araştırmacı çalışan performansını tek boyutlu bir kavram olarak ele alsa da çoğu araştırmacı tarafından çok boyutlu bir yapı olduğu iddia edilmektedir. Katz (1964), Sparrowe ve arkadaşları (2001) çalışan performansını rutin performans ve yenilikçi perfor- 
mans şeklinde çok boyutlu bir yapı olarak ele almaktadır. Rutin performansta çalışan iş tanımında belirtilen görev ve sorumlulukları yerine getirirken yenilikçi performansta çalışan iş tanımının ötesinde isteğe bağlı davranışlarda bulunma, işletmeye fayda sağlayacak yeni fikirlerin üretilmesi, benimsenmesi ve yeniliklerin başarıla uygulanması için gerekli gücün kazanılmasını içermektedir. Dolayısıyla yenilikçi performans işletme için önemli bir husus oluştururken örgütsel yeniliğin de özünü temsil etmektedir.

$\mathrm{Bu}$ araştırma ile literatürde daha önce incelenmediği görülen çalışanların işletmelerde iş amaçlı ve sosyal amaçlı sosyal medya kullanım düzeylerinin çalışanların yenilikçi performans düzeylerini ne yönde etkilediği ortaya konulmuştur. Bu kapsamda araştırmada nicel veri analiz yöntemi tercih edilerek, veriler SPSS 21 paket programı aracilığ ile analiz edilmiştir. Yapı geçerliliği için Açımlayıcı Faktör Analizi(AFA), güvenirlik için Cronbach's Alpha katsayısı hesaplanmıştır. Anket formlarından elde edilen verilerin analizinde öncelikle Açımlayıcı Faktör Analizi (AFA) gerçekleştirilmiştir. AFA sonucunda anket sorularının her birinin faktör yükleri incelendiğinde döndürülmüss bileşen matrisi s91 sorusunun faktör 2 ve faktör 3'de yakın ağırlıklı temsil edildiğinden dolayı s91 sorusu anketten çıkartılmış, s82 sorusu ise s9 grubuna kaydırılmıştır. Sonuçta anket 20 maddeli ve üç alt boyutu (iş amaçlı sosyal medya, sosyal amaçlı sosyal medya, yenilikçi performans) olan bir ölçek olarak kalmıştır. Yapı geçerliliği ve güvenirliği sağlandıktan sonra iş amaçlı, sosyal amaçlı ve yenilikçi puanlarının karşılaştırmasında Mann-Whitney U testi ve Kruskall-Wallis H testi kullanılmıştır. Şöyle ki, veriler normal dağılım göstermediğini için $t$ testi yerine Mann-Whitney $U$ Testi, Tek yönlü anova testi yerine Kruskall Wallis H Testi kullanılarak sonuçlar elde edilmiştir.

Mann-Whitney U testi kullanılarak iş amaçlı sosyal medya, sosyal amaçlı sosyal medya ve yenilikçi performans cinsiyet demografik değişkeni bakımından karşılaştırılmıştır. Cinsiyetler arasında puanlar açısından anlamlı bir farklılık görülmemekte, istatistiksel olarak anlamlı olmamakla birlikte iş amaçlı ve yenilikçi puanları kadınlarda daha yüksek görülmektedir. Kruskall Wallis $\mathrm{H}$ testi kullanılarak iş amaçlı sosyal medya, sosyal amaçlı sosyal medya ve yenilikçi performans eğitim demografik değişkeni açısından karşlaştırılmıştır. Çalışanların iş amaçlı ve sosyal amaçlı puanlarının yüksek lisans grubunda anlamlı derecede yüksek olduğu görülmekte, eğitim durumu arttıkça puanlarda artış olduğu sonucuna ulaşılmıştır. Yenilikçi puanı 
açısından gruplar arasında anlamlı bir farklılık görülmemektedir. İstatistiksel olarak anlamlı olmamakla birlikte ön lisans ve altı grubunda puanların daha düşük olduğu sonucuna ulaşılmıştır.

İş amaçlı sosyal medya, sosyal amaçlı sosyal medya ile yenilikçi performans arasındaki ilişkiye korelasyon analizi ile bakılmıştır. Anlamlılık seviyesi olarak 0,05 kullanılmış olup, $\mathrm{p}<0,05$ olması durumunda anlamlı farklılığın olduğu, $p>0,05$ olması durumunda ise anlamlı farklılı̆̆ın olmadığ belirtilmiştir.

Yapılan analiz neticesinde sosyal amaçlı sosyal medya kullanımı ile yenilikçi performans arasında anlamlı bir ilişki görülmediği sonucuna ulaşılmıştır. Literatür incelediğinde sosyal medya ile yenilikçi performans arasındaki ilişkiyi esas alan çalışmaya rastlanmamıştır. Bununla birlikte sosyal medya ile bireysel performans arasındaki ilişkiyi esas alan çalışmaların bulunduğu görülmektedir. Literatürdeki çalışmaların çoğunda sosyal medyanın bireysel performansı pozitif etkilediği sonucuna ulaşılmıştır.

İş amaçlı sosyal medya kullanımının yenilikçi performans üzerindeki etkisine ilişkin bulgular değerlendirildiğinde iş amaçlı sosyal medya kullanımının arttıkça yenilikçi performansın da arttığı görülmekte, ilişki anlamlı ancak düşük olarak değerlendirilmektedir. Yapılan analizler neticesinde ulaşılan sonuçlar literatürdeki benzer çalışmalarla örtüşmektedir.

Bu bilgiler ışığında yapılan araştırmanın hem literatüre hem iş hayatına faydalı bilgiler sağladığı söylenebilir. Yöneticiler açısından önemli olan bir durum performans türlerinden biri olan yenilikçi performansa önem vermesi durumunda işletmede sosyal medya kullanımlarını da bu yönde yapılandırması hususudur. Çalışanlar tarafından rutin görevlerin yerine getirilmesinin ötesinde işletmeye fayda sağlayacağı, yeni fikirlerin üretilmesi, tanıtılması ve gerçekleştirilmesi, olağan dışı sorunlarla, fırsatlarla ilgilenilmesinin arzu edildiği durumlarda, yönetici sosyal medyanın işletmelerde iş amaçı kullanımını teşvik edebilir ve bu yönde kullanılmasına izin verebilir. Bir diğer durum ise araştırmada çalışanların sosyal amaçlı sosyal medya kullanımı ile yenilikçi performansı arasında anlamlı bir ilişki bulunmadığından yöneticiler, çalışanların yenilikçi performanslarını göz önüne aldığında sosyal amaçlı sosyal medya kullanımlarının önemli bir etken olmadığ hususudur.

Araştırmada daha fazla sayıda banka çalışanına ulaşılmak istenmiş ancak mevcut şartlarda banka çalışanlarının yoğunluğu da göz önüne alınd1- 
ğında 111 katılımcının üzerine çıkılamamıştır. Araştırmanın sonuçları araştırmanın örneklemi ile sınırlandırılmıştır. Araştırma neticesinde ulaşılan bulgular bu kapsamda değerlendirilmiştir. Araştırmanın genellenebilirliğini artırmak adına gelecekte farklı sektörler ve farklı bölgelere geniş örneklem kitlelerine ulaşılarak literatüre önemli bir katkı sağlanabilir. 


\title{
EXTENDED ABSTRACT
}

\section{The Effect Of Workers' Use Of Social Media On Innovative Performance}

\author{
Yunus Bahadır Güler - Nurgül Göksal \\ Kırıkale University
}

Today, the use of social media is increasing rapidly. These applications are used by businesses as well as individual users. The social media used by the employees in the enterprises are handled in two ways as business and social purposes. In the use of social media for business purposes, the exchange of information and content related to the basic business is enabled and thus, the contribution of organizational communication is realized quickly and easily. Businesses are increasingly aligning their use of social media with strategic management, organizational communication and public relations. In the use of social media for social purposes, employees share social, informal, personal and emotional exchanges in the workplace. Innovative performance is one of the issues that can be related to the social media used by employees in the enterprises. Innovative performance is defined as the deliberate production, promotion and realization of new ideas by the employees in order to benefit from the operation and to make the employees behave voluntarily beyond the job description. This research is conducted to determine the extent to which the use of social media for business and social impacts affects the innovative performance levels of employees. The population of the study consists of 127 bank employees working in the same bank in Ankara. Survey method was used in the research. The questionnaires were distributed to the Bank's employees through face-to-face interviews. However, 111 of 127 questionnaires were given back to the participants and the return rate was $88 \%$. In the research, it was ensured that the Bank employees and senior managers completed the questionnaire forms.

Within the framework of the literature review conducted in accordance with the purpose of the research, the scale developed by Zoonen et al. (2014) for business social media and Zhang et al. (2018) for social purposes were used to reveal the extent to which the employees use social media for 
business and social purposes. In the scale, social media for business purposes consists of seven items and social media for social purposes consists of five items. The scale other than the social media scale is the innovative performance scale. The innovative performance scale was developed by Janssen (2004). The scale consists of nine items. These scales were graded according to the 5-point Likert scale. Bank employees were asked to indicate on a 5-point Likert-type scale how the statements indicated in the questionnaire fit them. Then, the collected questionnaire data were transferred to SPSS program and evaluated.

Exploratory Factor Analysis was conducted for the social media usage levels and innovative performance levels of the employees (in other words 8., 9. And 10th Question). According to the KMO (Kaiser-Meyer-Olkin) test, it can be said that the data obtained for exploratory factor analysis is suitable for factor analysis and the number of subjects is sufficient ( $p$ $<0.005$ ). Using the Explained Total Variance Table, it is seen that the eigen value consists of 3 factors with a value greater than 1. In Exploratory Factor Analysis, various methods are used to determine the number of subdimensions. In this study, Slope Accumulation Graph was used to determine the number of sub-dimensions. In the graph analysis, the number of factors is 3 .

Factor analysis has two stages: factor extraction and factor rotation. As a result of factor extraction analysis, it has been proved that the scale has only three sub-dimensions. There are two types of rotation method in factor rotation. These are vertical rotation and oblique rotation methods. In vertical rotation, there is no correlation between the factors. Other method is widely used in social studies. As the result of the rotated component matrix, s91 is represented in factor 2 and factor 3, it is recommended to remove s91 from the questionnaire and to shift s 82 to the s9 group. Since factor analysis was repeated after each discarded variable, the s91 question was removed and explanatory factor analysis (AFA) was performed again. Step 2 When the AFA results - KMO and Barlett's Test tables are examined, it is seen that the data and sample are sufficient according to KMO index in step $2(\mathrm{p}<0.05)$. Step 2 AFA Results- According to the explained Total Variance Chart, a 3-factor structure with an Eigen value (initial eigenvalues) greater than 1 is observed. Step 2 AFA Results- When the Slope Accumulation Chart is examined, it is seen that there are three factors. 
When the factor loads are analyzed as a result of the Rotated Component Matrix, it is seen that the weights are 0.5 and above. It can be said that it is a three-factor structure. In this structure, we can define the dimensions as follows;

- Size 1: For business purposes (s81, s83, s84, s85, s86, s87)

- Size 2: For social purposes (s82, s92, s93, s94, s95)

- Size 3: Innovative Performance (s101, s102, s103, s104, s105, s106, s107, s108, s109)

S82 and S9 were included in the scale and the question of s91 was omitted from the scale. As a result, it remained a scale with 20 items and three sub-dimensions. Cronbach's Alpa internal consistency coefficient is calculated to measure the reliability of the resulting scale. Alpha values are higher than 0.7. In this respect, the reliability of all sub-dimensions is considered sufficient.

The frequencies of the demographic variables (age, monthly income, working year, gender and educational status of the employees) were calculated and the table were made. As a result of the frequencies of the social media applications used by the employees in the bank, it is seen that the employees mostly prefer whatsapp.

Social media and innovative performance were compared in terms of age and monthly income of employees. As a result of the analysis, there is a significant and similar but low-level relationship between monthly income and social use score. $(\mathrm{p}<0.05 ; \mathrm{r}=0.204)$ As the monthly income increases, the usage score for social purposes increases.

There is a significant, inverse but low relationship between working year in business and using social media for business purposes $(\mathrm{p}<0.05 ; \mathrm{r}=$ -0.211). As business year increases, the scores of using social media for business purposes decrease.

Before the necessary analysis for research, Shapiro-Wilk normality test is used to determine whether each of the variables "business", "social" and "innovative performance" show normal distribution. The significance level for this research is determined as .05. In addition, Shapiro-Wilk normality test was conducted based on gender and educational demographic variables. As a result, our data do not show normal distribution. Since the distribution of our data does not fit the normal distribution, non- 
parameter statistical methods should be used. The results were obtained by applying Mann-Whitney $U$ Test which is equivalent to T-test and Kruskall-Wallis H Test which is equivalent to One Way Anova test. As a result of Mann-Whitney $U$ test, there was no significant difference between the genders in terms of scores ( $p>0.05)$. Although it is not statistically significant, business and innovative scores are higher in women. As a result of Kruskall Wallis $\mathrm{H}$ Test, the scores of business and social purposes were found to be significantly higher in the bachelor's degree group ( $\mathrm{p}$ $<0.05)$.

There was no significant difference between the groups in terms of innovative score $(\mathrm{p}>0.05)$.

Although not statistically significant the scores of the associate degree and six groups were lower. In accordance with the purpose of the study, the relationship between the levels of social media use for business and social purposes and the innovative performance of employees is examined using the correlation table. As a result of the analysis, the higher the business social media score, the higher the innovative performance score ( $\mathrm{p}$ $<0.05 \mathrm{r}=0.235$ ). The relationship was significant but low. When the relationship between social media use and innovative performance is considered, there is no significant relationship between the two variables $(\mathrm{p}=$ $0.103>0.05)$.

\section{Kaynakça / References}

Aral, S., Dellarocas, C. ve Godes, D. (2013). Introduction to the special issuesocial media and business transformation: A Framework for research. Information Systems Research, 24(1), 3-13.

Bingöl, D. (2014). İnsan kaynakları yönetimi. İstanbul: Beta Basım Yayım Dağıtım A.Ş.

Bruns, A. (2009). Social media: Tools for user-generated content social drivers behind growing consumer participation authors acknowledgment. Avustralya: Smart Services CRC Pty Ltd.

Büyüköztürk, Ş. (2018). Sosyal bilimler için veri analizi el kitabı istatistik: Araştırma deseni SPSS uygulamaları ve yorum. Ankara: Pegem Akademi Yayıncilı.

Cao, Xi., Guo, X., Vogel, D. ve Zhang, X. (2016). Exploring the influence of social media on employee work performance. Emerald Internet Research, 26(2), 529-545. 
Chung, A. Q. H., Andreev, P., Benyoucef, M., Duane, A. ve O'Reilly, P.. (2017). Managing an organisation's social media presence: An empirical stages of growth model. International Journal of Information Management, 37(1), 1405-1417.

Chung, A. Q. H., Andreev, P., Benyoucef, M., Duane, A. ve O'Reilly, P.. (2018). Where the shoe pinches: Realizing dominant problems as an organizational social media business profile evolves. International Journal of Information Management, 41(1), 33-49.

Çetinkaya, A. S. ve Rashid, M.. (2018). The effect of social media on employees' job performance: The mediating role of organizational structure. Journal of Organizational Psychology, 18(4), 94-116.

DiStaso, M. W., McCorkindale, T. ve Wright, D. K. (2011). How public relations executives perceive and measure the impact of social media in their organizations. Public Relations Review, 37(3), 325-328.

Eşmekaya, E. (2019). Faktör analizi. YBS Ansiklopedi, 7(1), 24-35.

İraz, R. ve Akgün, Ö. (2011). Örgütsel bağlılı̆̆ın çalışan performansı üzerine etkilerini ölçmeye yönelik bir çalışma. Selçuk Üniversitesi Sosyal Bilimler Meslek Yüksek Okulu Dergisi, 14(1-2), 225-250.

Gonzalez, E. S., Riemenschneider, C., Leidner, D. E. ve Koch, H.. (2013). The impact of internal social media usage on organizational socialization and commitment. Milan: Thirty Fourth International Conference on Information Systems.

Gürbüz, S. ve Şahin, F.. (2018). Sosyal bilimlerde araştırma yöntemleri. Ankara:Seçkin Akademi ve Mesleki Yayınlar.

Jassen, O. (2004). Employees' goal orientations, the quality of leader-member exchange, and the outcomes of job performance and job satisfaction. Academy of Mangement Journal, 47(3), 368-384.

Jarrahi, M. H. (2011). Social networking, social network technologies, and the enterprise. In Proceedings of the 2011. 688-690.

Jouda, A. A., Ahmad, U. N. U. ve Dahleez, K. A. (2016). The impact of human resource management practices on employees performance: The case of islamic university of Gaza in palestine. International Review of Management and Marketing, 6(4), 1080-1088.

Haddud, A., Dugger, J. C. ve Gill, P. (2016). Exploring the Impact of Internal Social Media Usage on Employee Engagement. Journal of Social Media for Organizations, 3(1), 1-22. 
Hassam, A. H., Nevo, D., ve Wade, M.. (2015). Linking dimensions of social media use to job performance: The role of social capital. Journal of Strategic Information Systems, 24(2), 65-89.

Kaplan, A. M. ve Haenlein, M. (2009). The fairyland of second life: Virtual social worlds and how to use them. Business Horizons, 52(6), 563-572.

Katz, D. (1964). The motivational basis of organizational behavior. Behavioral Science, 9,131-146.

Leftheriotis, I., G., Michail N. (2014). Using social media for work: Losing your time or improving your work?. Computers in Human Behavior, 31, 134142.

Macnamara, J., ve Zerfass, A. (2012). Social media communication in organizations: The challenges of balancing openness, strategy, and management. International Journal of Strategic Communication, 6(4), 287-308.

Md-Sidin, S., Sambasivan, M. ve Muniandy, N. (2009). Impact of psychological ownership on the performance of business school lecturers. Journal of Education for Business, 85(1), 50-56.

Nduhura, D. ve Prieler, M. (2017). When I chat online, 1 feel relaxed and work better: Exploring the use of social media in the public sector workplace in Rwanda. Telecommunication Policy. 41(7-8), 708-716.

Piller, F. T., Vossen, A. ve Ihl, C. (2012). From social media to social product development: The impact of social media on co-creation of innovation. Die Unternehmung, 66(1), 7-27.

Rathore, S. ve Panwar, A. (2016). A framework for employee engagement through social media: Current trends and practices. High Tech People High Touch HR: Are me missing the humane touch? içinde (s.87-104),

Šikýř, M. (2013). Best practices in human resource management: the source of excellent performance and sustained competitiveness. Central European Business Review, 2(1), 43-48.

Song, Q., Wang, Y., Chen, Y., Benitez, J., Hu, J.. (2019). Impact of the usage of social media in the workplace on team and employee performance. Information and Management, 1-20.

Suliman, Abubakr M.T. (2001). Work performance: Is it one thing or many things? The multi dimensionality of performance in a Middle Eastern context. The International Journal of Human Resource Management, 12(6), 1049-1061. 
Sparrowe, R. T., Liden, R. C., Wayne, S. J.,ve Kraimer, M.. (2001). Social networks and the performance of individuals and groups. The Academy of Management Journal. 44(2), 316-325.

Tajudeen, F. P., Jaafar, N. I. ve Ainin, S. (2018). Understanding the impact of social media usage among organizations. Information and Management, 55(3), 308-321.

Taylor, M., Haggerty, J., Gresty, D., Wren, C., ve Berry, T. (2016). Avoiding the misuse of social media by employees. Network Security,5, 8-11.

Yaratan, H. (2017). Sosyal bilimler için temel istatistik SPSS uygulamall. Ankara: Anı Yayıncilik.

Zhang, X., Ma, L., Xu, B., ve Xu, F.. (2018). How social media usage affects employees' job satisfaction and turnover intention: An empirical study in China. Information and Management.56(6), 1-12.

Zhang, X. ve Venkatesh, V. (2013). Explaning employee jop performance: The role of online and offline workplace communication networks. Management Information Systems. 37(3). 695-722.

Zoonen, W. V., Meer, T. G. L. A., Van Der, V., ve Joost W. M. (2014). Employees work-related social-media use : His master' s voice. Public Relations Review,40(5), 850-852.

Zoonen,W. Van, V., Joost W. M., ve Vliegenthart, R. (2017). Understanding the consequences of public social media use for work. European Management Journal, 35(5), 595-605.

\section{Kaynakça Bilgisi / Citation Information}

Güler, B. Y. ve Göksal, N. (2020). Çalışanların sosyal medya kullanımının yenilikçi performans üzerindeki etkisinin araştırılması. OPUSUluslararası Toplum Araştırmaları Dergisi, 15(24), 2297-2334. DOI: 10.26466/opus.635371 